TRABALHO EM CONDIÇÃO ANÁLOGA À DE ESCRAVO NO MEIO URBANO: ANÁLISE DAS TEORIAS DA RESPONSABILIDADE APLICÁVEIS À CADEIA PRODUTIVA NA INDÚSTRIA TÊXTIL

Dissertação de Mestrado

Orientador: Professor Doutor Ronaldo Lima dos Santos

UNIVERSIDADE DE SÃO PAULO

FACULDADE DE DIREITO

São Paulo-SP

2019 


\title{
TRABALHO EM CONDIÇÃO ANÁLOGA À DE ESCRAVO NO MEIO URBANO: ANÁLISE DAS TEORIAS DA RESPONSABILIDADE APLICÁVEIS À CADEIA PRODUTIVA NA INDÚSTRIA TÊXTIL
}

\begin{abstract}
Dissertação apresentada à Banca Examinadora do Programa de Pós-Graduação em Direito, da Faculdade de Direito da Universidade de São Paulo, como exigência parcial para obtenção do título de Mestre em Direito, na área de concentração Direito do Trabalho e da Seguridade Social, sob a orientação do Prof. Dr. Ronaldo Lima dos Santos.
\end{abstract}




\section{Ficha Catalográfica}

Gondim, Andrea da Rocha Carvalho

Trabalho em condição análoga à de escravo no meio urbano: análise das teorias da responsabilidade aplicáveis à cadeia produtiva na indústria têxtil / Andrea da Rocha Carvalho Gondim. - São Paulo: USP / Faculdade de Direito, 2019.

$251 \mathrm{f}$

Orientador: Prof. Dr. Ronaldo Lima dos Santos.

Dissertação (Mestrado), Universidade de São Paulo, USP, Programa de Pós-Graduação em Direito, área de concentração Direito do Trabalho e da Seguridade Social, 2019.

1. Trabalho escravo. 2. Cadeia produtiva. 3. Responsabilidade civil. 4. Direitos humanos. 5. Indústria têxtil. I. Santos, Ronaldo Lima dos. II. Título. 
BANCA EXAMINADORA

Orientador: Prof. Dr. Ronaldo Lima dos Santos 
Aos meus pais e às minhas irmãs que desde cedo me ensinaram o valor da família e da empatia. Ao meu esposo que é amor nos momentos mais dificeis e à minha filha que me faz querer um mundo melhor não só para ela, mas para as futuras gerações. 


\section{AGRADECIMENTOS}

Agradeço, primeiramente, a Deus pelas bênçãos recebidas, à minha família pelo suporte de sempre e à minha amiga Ana Angélica de Araújo Ponte cuja morte prematura me recorda diuturnamente que enquanto estamos vivos, precisamos ter coragem para lutar.

Não poderia deixar de agradecer aos colegas aguerridos do Ministério Público do Trabalho(MPT), carreira pela qual tenho imenso orgulho de fazer parte, notadamente aos amigos Tiago Cavalcanti, Ricardo Ballarini e Gustavo Accioly que me encorajaram no início do curso de Mestrado, às amigas Christiane Nogueira, Cristiane Sbalqueiro e Tatiana Bivar que ajudaram com críticas e sugestões e aos amigos da Procuradoria do Trabalho no município de Guarulhos, Patrícia Patruni, Raquel Perales Aguiar e Coppola, pois são inspiração de vida e trabalho e contribuíram, cada um à sua maneira, para que eu alcançasse meu desiderato.

Agradeço a confiança depositada pelo Prof. Dr. Ronaldo Lima dos Santos, cuja amizade construída durante o mestrado em São Paulo só fez crescer a admiração pelo seu brilhante trabalho como professor e colega de MPT.

Aos competentes e comprometidos auditores-fiscais do trabalho que superam todos os problemas orçamentários para fazer valer os direitos dos trabalhadores, especialmente o Chefe da Fiscalização do Trabalho Escravo em São Paulo, André Roston, com quem tive o prazer de trabalhar, ainda que brevemente. E aos demais atores sociais e instituições que lutam pela erradicação desta chaga que mancha nossa história, cada um ao seu modo, mas com importante papel nesta rede que busca defender o direito da pessoa humana de não ser submetida ao trabalho em condição análoga à de escravo.

Agradeço à minha irmã Adriana que despertou meu olhar desde cedo para o valor transformador da educação, verdadeira inspiração e motivação para a vida acadêmica.

Agradeço minha prima-filha-irmã-amiga Lorena Leite Aragão pela leitura crítica e todo seu apoio na revisão deste trabalho, e por compartilhar as dificuldades da vida acadêmica em momentos de tantos ataques e retrocessos sociais, o que me remete a mais um agradecimento, desta vez ao Grupo de Pesquisa Trabalho e Capital (USP), que possui valor inestimável pela humildade e sabedoria do Prof. Dr. Jorge Luiz Souto Maior em permitir aos alunos o livre exercício do pensar. 
TRABALHO ESCRAVO NO BRASIL NÃO AO TRABALHO ESCRAVO

A história da escravidão Vem desde a antiguidade

Mas permanece terrível E sempre com crueldade Vive ainda presente Também na atualidade.

Hoje ela é sorrateira De uma forma disfarçada Não há troncos e correntes

Mas continua atrelada Ao simples trabalhador E a mão de obra forçada.

Foi no século dezenove

A famosa abolição Assinou-se a lei Áurea E a falsa libertação Mas convivemos até hoje

Com a tal escravidão. (...)

Vamos unir nossas forças Vamos sim erradicar Essa prática desumana Vamos logo denunciar Ao ministério público Que irá investigar.

Fique de olho aberto Para não virar escravo Essa prática é um insulto

Pro cidadão um agravo Deixa o homem infeliz E o nosso Deus fica bravo.

Juarês Alencar Pereira, Literatura de Cordel. 
GONDIM, Andrea da Rocha Carvalho. Trabalho em condição análoga à de escravo no meio urbano: análise das teorias da responsabilidade aplicáveis à cadeia produtiva na indústria têxtil. 2019. 251f. Dissertação (Mestrado). Faculdade de Direito da Universidade de São Paulo, São Paulo, 2019.

\section{RESUMO}

No Brasil, foram detectados 43.696 casos de trabalho análogo à de escravo entre os anos de 2003 e 2017. Desses casos, foi observado o surgimento de denúncias relacionadas à cadeia produtiva da indústria têxtil, notadamente em oficinas de costuras subcontratadas de grandes varejistas detentoras de marcas renomadas nacional e internacionalmente. Essa constatação foi o que motivou a presente pesquisa que analisou quatro casos nos quais houve constatação de trabalho escravo na cadeia produtiva têxtil. Os casos analisados foram escolhidos porque contemplaram a mesma situação fática de trabalho escravo pela ação fiscalizadora do Ministério do Trabalho e Emprego (MTE) com desfechos distintos perante o Ministério Público do Trabalho (MPT), através de assinatura de termo de ajustamento de conduta às exigências legais ou pelo Poder Judiciário trabalhista, em ações anulatórias de autos de infração ou ação civil pública. A partir do estudo dos quatro casos, percebeu-se a urgência de analisar as teorias acerca da responsabilidade aplicáveis na cadeia produtiva da indústria têxtil, apresentando as diversas abordagem utilizadas para fundamentar as ações judiciais e extrajudiciais, quando constatado trabalho escravo, no contexto da reestruturação produtiva, das pressões do mundo globalizado e da nova engenharia das empresas que obscurecem a responsabilidade das empresas líderes do setor que cria diversas figuras fragmentadas na produção como forma de burlar a responsabilidade laboral. A pesquisa é interdisciplinar e transdisciplinar com o uso do método hipotético-dedutivo bibliográfica e qualitativa, com base em documentos oficiais da base de dados do MTE, MPT e Justiça do Trabalho. Defendemos uma ressignificação da responsabilidade da empresa líder na cadeia produtiva em que há exploração dos produtos que levam sua marca, quando constatado trabalho em condição análoga à de escravo, independentemente do título jurídico sobre as quais se estabeleceram a relação laboral. Dessa forma, seriam otimizadas as ações que superam a noção de indicação dos culpados para obter a responsabilidade daqueles que desenvolvem seus produtos sem observar os direitos humanos dos trabalhadores ativados em sua cadeia.

Palavras-chave: Trabalho escravo. Cadeia produtiva. Responsabilidade civil. Direitos humanos. Indústria têxtil. 
GONDIM, Andrea da Rocha Carvalho. Trabalho em condição análoga à de escravo no meio urbano: análise das teorias da responsabilidade aplicáveis à cadeia produtiva na indústria têxtil. 2019. 251p. Master's Thesis - Faculty of Law, University of São Paulo, São Paulo, 2019.

\begin{abstract}
In Brazil, from 2003 to 2017 it was verified 43,696 cases of workers in situation analogous to slavery. In this context, a considerable number of complaints concerned the supply chain of the textile industry, especially at the sewing office branch. Those sewing offices were hired by major local or global retail companies. This acknowledgment motivated the current research which analyzed four cases where it was verified the occurrence of workers in condition analogous to slavery at the supply chain of the textile industry. The cases were chosen because they presented workers in situations analogous to slavery as appointed by the audition of the Ministry of Labor and Employment (MTE) with outcomes different when compared to the Federal Labor Prosecution (MPT), which assigned a Term for Commitment to Adjustment of Conduct (TAC) in order to meet the legal requirements or by the Labor Judiciary which used Annulment Lawsuits of infraction notices or public civil suit. Surveying the aforementioned cases, it was noticed that it is urgent to analyze the theories underlying the applicable responsibilities in the supply chain of the textile industry, presenting the different approaches used to ground the judicial and extrajudicial action in a context of productive restructuring, globalization pressure as well as the recent company engineering that helps to blur the responsibilities of the major retailers which create fragmented characters at the production line as a way to circumvent the law as far as their labor responsibility is concerned. This study is interdisciplinary and transdisciplinary and used the hypothetico-deductive method through a qualitative analysis. It was possible to carry out a bibliographic research due to the official government documents on the data basis of MTE, MPT and Labor Court. We advocate the reframing of the responsibility of the major retailer at the supply chain in which there is exploitation of products that take its brand when it is verified the presence of working condition analogous to slavery, independent to the legal title that attaches the labor connection. Thus, actions would overcome the notion of who is to blame and would focus on companies which do not observe the human rights of those involved on the supply chain of their products.
\end{abstract}

Keywords: Slavery labor. Supply chain. Civil responsibility. Human rights. Textile industry. 


\section{LISTA DE ILUSTRAÇÕES}

Figura 1: Estrutura da cadeia produtiva do setor têxtil e de confecção...........................................63

Figura 2. Quadro sinótico da cadeia produtiva e figuras correlatas............................................... 71

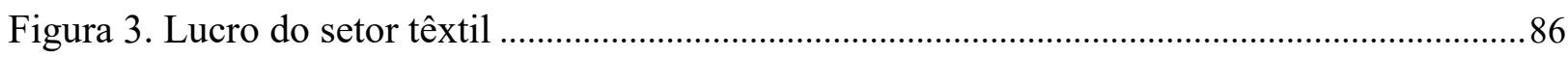

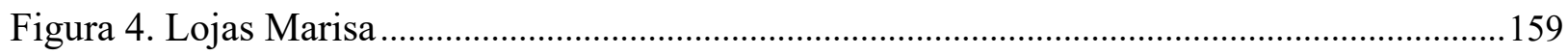

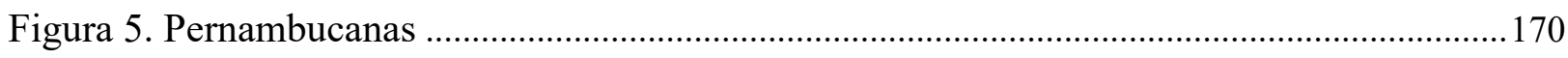

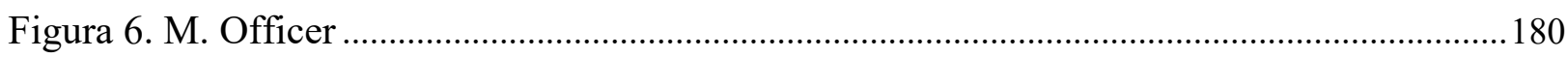

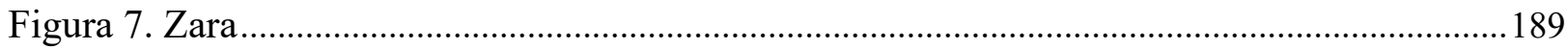

Gráfico 1. Descumprimento de normas de meio ambiente do trabalho ......................................... 135 


\section{LISTA DE ABREVIATURAS}

ABIT Associação Brasileira da Indústria Têxtil e de Confecção

BNDES Banco Nacional de Desenvolvimento Econômico e Social

CC Código Civil

CDC Código de Defesa do Consumidor

CLT Consolidação das Leis do Trabalho

CP Código Penal

CPC Código de Processo Civil

CPI Comissão Parlamentar de Inquérito

CPT Comissão Pastoral da Terra

CRFB Constituição da República Federativa do Brasil

CTPS Carteira de Trabalho e Previdência Social

EC Emenda à Constituição

ECA Estatuto da Criança e Adolescente

EMN Empresa Multinacional

GEFM Grupo Especial de Fiscalização Móvel

GERTRAF Grupo Executivo de Repressão ao Trabalho Forçado

IC inquérito civil

IN instrução normativa

IPEC Programa Internacional para a Erradicação do Trabalho Infantil

JT Justiça do Trabalho

LINDB Lei de introdução às normas do direito brasileiro

MDSA Ministério do Desenvolvimento Social e Agrário

MF Ministério da Fazenda

MIRAD Ministério da Reforma e Desenvolvimento Agrário

MP Ministério Público

MPF: Ministério Público Federal

MPT: Ministério Público do Trabalho

MSI Iniciativas Multipartidas

MTE Ministério do Trabalho e Emprego 
MTPS Ministério do Trabalho e Previdência Social

OCDE Organização para a Cooperação e o Desenvolvimento Económico

OIT/ILO Organização Internacional do Trabalho/ International Labour Organization

OMC Organização Mundial do Comércio

ONG Organização Não-Governamental

ONU Organização das Nações Unidas

PEC Proposta de Emenda à Constituição

PME Pequenas e Médias Empresas

P.O. Princípios Orientadores da ONU

RSE Responsabilidade Social das Empresas

SINAIT Sindicato nacional dos Auditores Fiscais do Trabalho

SIT Secretaria de Inspeção do Trabalho

SRSG Representante Especial para empresas e Direitos Humanos

SRTE Superintendência Regional do Trabalho e Emprego

SST Segurança e Saúde no Trabalho

STF Supremo Tribunal Federal

STJ Superior Tribunal de Justiça

SUS: Sistema Único de Saúde

TAC Termo de ajuste de conduta

TRF: Tribunal Regional Federal

TRT: Tribunal Regional do Trabalho

TST Tribunal Superior do Trabalho

UN United Nations

UNCTAD: Conferência das Nações Unidas sobre o Comércio e o Desenvolvimento UNHCR: Alto Comissariado das Nações Unidas para os Direitos Humanos 


\section{SUMÁRIO}

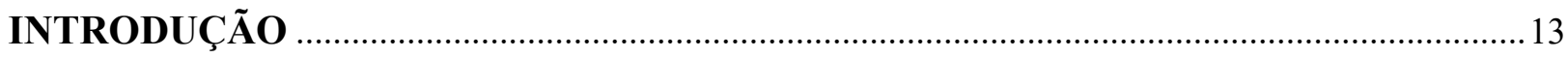

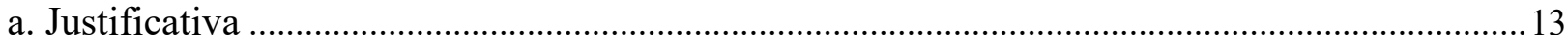

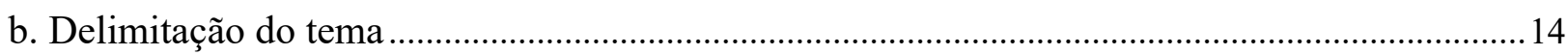

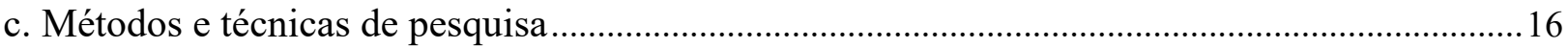

1 TRABALHO EM CONDIÇÃO ANÁLOGA À DE ESCRAVO …......................................... 17

1.1 Noções históricas acerca do trabalho escravo ........................................................................ 17

1.2 Trabalho em condição análoga à de escravo na indústria têxtil .................................................32

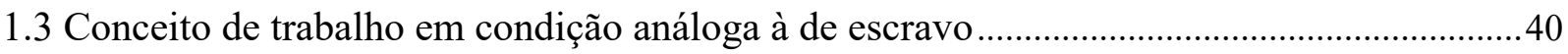

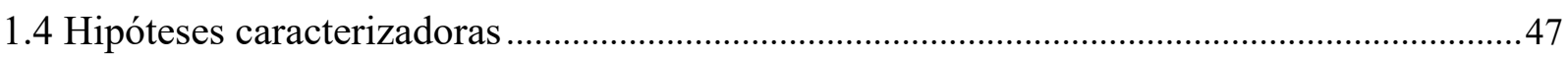

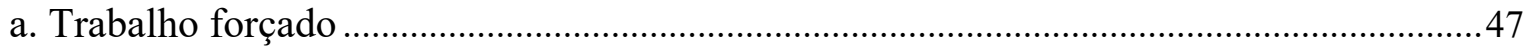

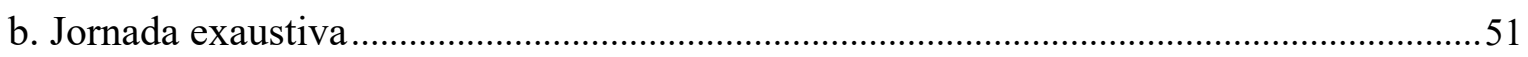

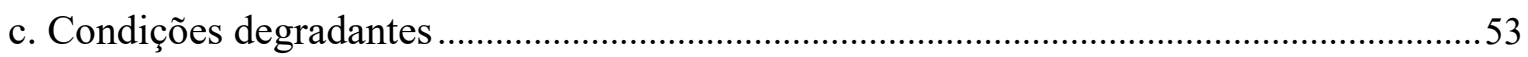

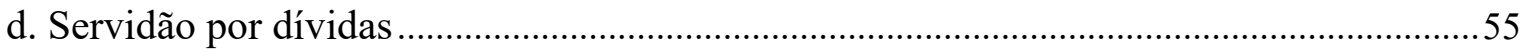

e. Figuras equiparadas ao trabalho em condição análoga à de escravo .................................57

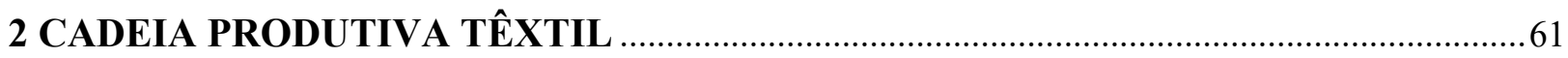

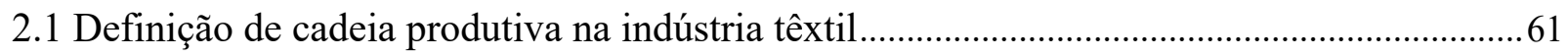

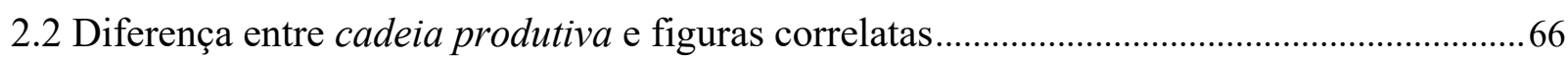

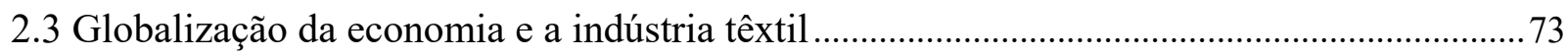

2.4 A cadeia produtiva da indústria têxtil e a precarização do trabalho ......................................... 81

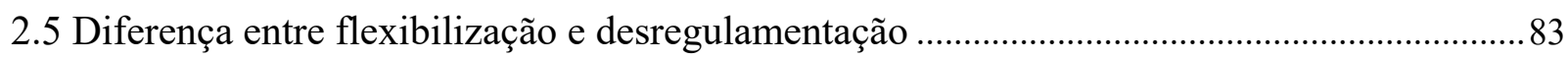

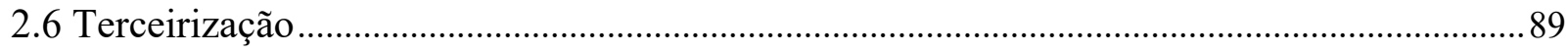

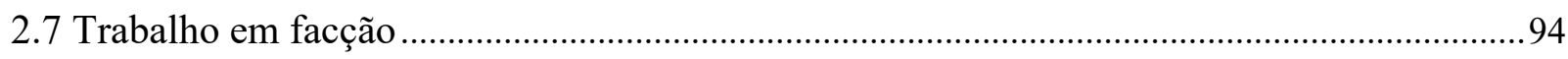

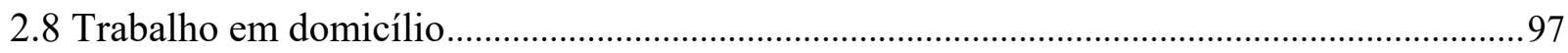

\section{RESPONSABILIDADE CIVIL E CADEIA PRODUTIVA NA INDÚSTRIA} TÊXTIL

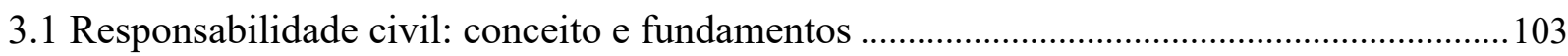

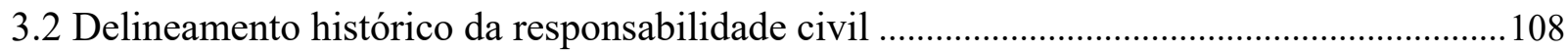

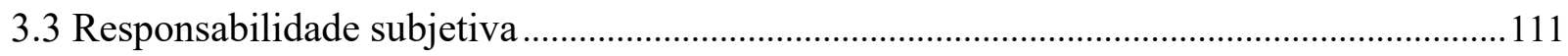

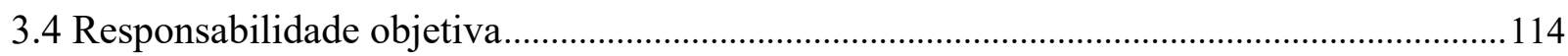

3.5 Teoria da responsabilidade objetiva por ato dos prepostos ou empregados: subordinação jurídica estrutural (reticular) e integrativa (objetiva) ...................................... 119

3.6 Teoria da responsabilidade do fornecedor do produto por dano ao consumidor ..................128

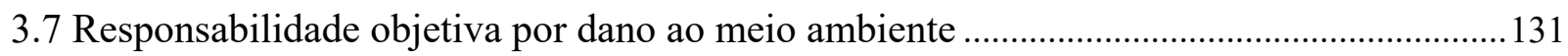

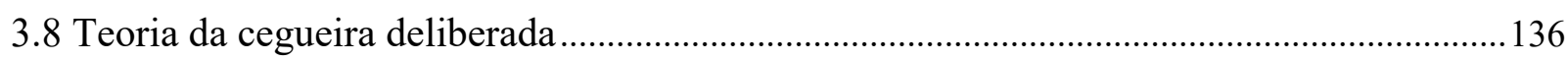

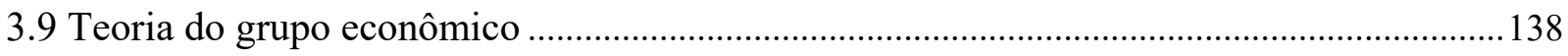


3.10 Teoria dos contratos coligados, conexos e rede contratuais ................................................ 142

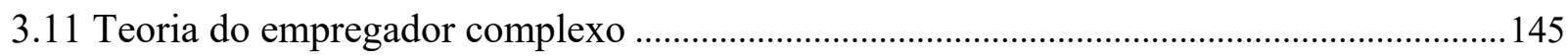

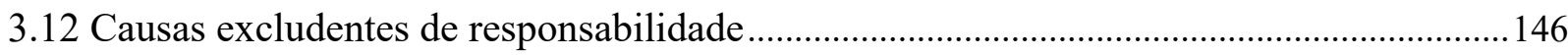

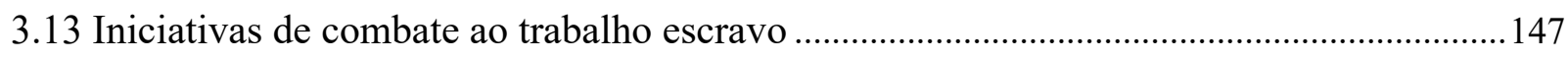

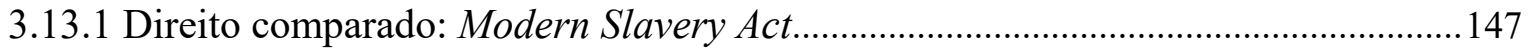

3.13.2 Usos e costumes internacionais: Princípios orientadores da ONU............................ 152

4. CASOS DE TRABALHO EM CONDIÇÃO ANÁlOGA À DE ESCRAVO NO

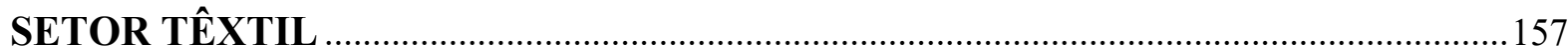

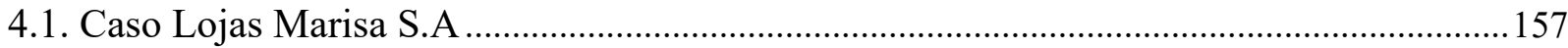

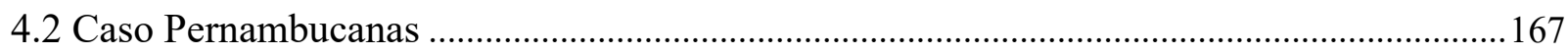

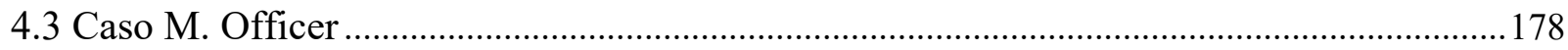

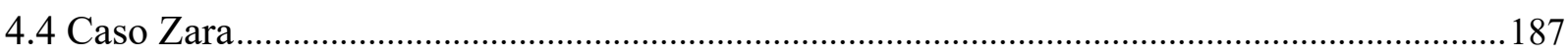

4.5 Síntese da análise da responsabilização na cadeia produtiva na indústria têxtil...................199

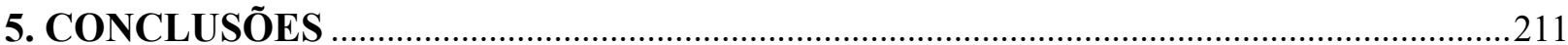

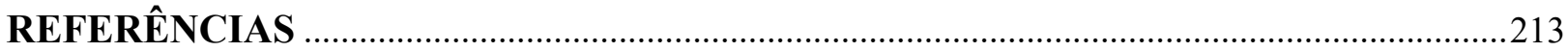




\section{INTRODUÇÃO}

\section{a. Justificativa}

A Fundação Internacional Walk Free estima que atualmente cerca de 45 milhões de pessoas são mantidas em alguma forma de escravidão em todo o mundo ${ }^{1}$, das quais 160.100 (cento e sessenta mil e cem) vivem no Brasil, seja no campo ou na cidade $^{2}$.

O Ministério do Trabalho e Emprego (MTE) divulgou que, desde a década de 1990, foi crescente número de denúncias envolvendo trabalhadores, em sua maioria migrantes indocumentados, reduzidos em condição análoga à de escravo na indústria têxtil, sobretudo na produção de roupas e demais artigos têxteis que compõem o setor de confecções no Estado de São Paulo (2012).

Pela presente pesquisa buscamos analisar as teorias da responsabilidade aplicáveis à cadeia produtiva na indústria têxtil a partir de quatro casos de trabalho em condição análoga à de escravo que receberam visibilidade após ação fiscalizadora do MTE realizadas em oficinas de costuras da cadeia produtiva de grandes varejistas detentoras de marcas renomadas nacional e internacionalmente, como Zara (PYL; HASHIZUME, 2011), Pernambucanas (TRT mantém condenação da Pernambucanas por trabalho escravo, 2017), Marisa (ROLLI; FERNANDES, 2010) e M.Officer (APÓS denúncias de trabalho escravo, 2014). A escolha decorreu do fato de eles contemplarem a mesma situação fática pela ação fiscalizadora como redução de trabalhadores em condição análoga à de escravo na cadeia produtiva das varejistas, mas com desfechos distintos perante o Ministério Público do Trabalho (MPT), por meio de assinatura de termo de ajustamento de conduta às exigências legais ou pelo Judiciário trabalhista, em sede de ações anulatórias de autos de infração ou ação civil pública ajuizada pelo MPT.

A abolição da escravatura, em 1888, cedeu lugar a novos tipos de exploração dos trabalhadores que caracterizam o tipo penal do trabalho em condição análoga à de escravo ${ }^{3}$

\footnotetext{
${ }^{1}$ Informação extraída da Fundação Walk Free. Disponível em: <https://www.walkfreefoundation.org>. Acesso em: 10 maio 2017.

${ }^{2}$ Conferir em índice sobre escravidão global. UNRAVELLING the numbers. The Global Slavery Index. Disponível em: <https://www.globalslaveryindex.org/findings/>. Acesso em: 10 maio 2017.

${ }^{3}$ Voltaremos ao tema ao abordar o conceito de trabalho em condição análoga à de escravo. Todavia, é de bom alvitre antecipar que a norma penal considerou, no art. 149 do CP, como figura típica a exploração de trabalho em condição análoga, semelhante, similar à de escravo, uma vez que juridicamente a escravidão estava abolida.
} 
como fenômeno não exclusivo do meio rural, como se observa com os flagrantes de trabalho em condição análoga à de escravo em oficinas de costura em São Paulo. Para robustecer o combate ao trabalho nessas condições, além do esforço estatal, é necessário que empregadores e empresas adotem medidas efetivas para identificar, prevenir e mitigar os riscos do trabalho forçado ou obrigatório com a imposição de responsabilidade por tal prática em suas cadeias, reconhecendo a evolução histórica do conceito de trabalho escravo.

A multiplicidade de termos relacionados à cadeia produtiva que se colocam entre 0 trabalhador, reduzido em condição análoga à de escravo, e a responsabilização da empresa, detentora do poder econômico e que explora a marca, nos conduziu a revisitar o Direito que se aplica tendo como norte os direitos humanos e a efetividade dos direitos sociais para além da mera indicação dos culpados.

A exploração da atividade econômica é possível desde que ocorra sem abuso de Direito, em consonância com a Constituição Federal, com normas internacionais e infraconstitucionais. Desse modo, a responsabilidade na cadeia produtiva busca atender aos anseios de justiça sobrepondo a dignidade da pessoa humana à defesa do mercado, independentemente do título jurídico sobre as quais se estabeleceram a relação laboral para realmente efetivar os direitos fundamentais dos trabalhadores ativados em uma cadeia produtiva.

\section{b. Delimitação do tema}

Para a consecução dos objetivos, no primeiro capítulo percorre-se o caminho histórico para melhor apreensão do trabalho escravo, tão comentado e tão pouco compreendido. O resgate histórico utiliza as fontes secundárias de pesquisa teórica bibliográfica, a partir dos estudos de Eric Williams, Claude Meillassoux, Moses Finley, Dale Tomich, Caio Prado Jr., Kátia Mattoso, José Murilo de Carvalho, Ricardo Rezende, Ricardo Antunes, Tiago Cavalcanti, José Cláudio Monteiro de Brito Filho, Harry Braverman e David Harvey, dentre outros.

O capítulo segundo define a cadeia produtiva, traçando a diferença entre cadeia produtiva e figuras correlatas, como cadeia de suprimentos, cadeia global de valor e rede de produção global, demonstrando como o termo foi utilizado pelas autoridades que se depararam com os quatros casos analisados. Há, ainda, a intersecção entre cadeias 
produtivas, globalização, reestruturação produtiva e organização do trabalho no setor têxtil que induziram a competitividade através de formas precárias de trabalho, como o trabalho terceirizado, em domicílio e a facção, com as fontes de pesquisa documental (análise de convenções coletivas de trabalho do setor) e bibliográfica.

O capítulo terceiro visita a teoria da responsabilidade civil, seu conceito, fundamentos e delineamento histórico para possibilitar o estudo das teorias acerca da responsabilidade aplicadas e aplicáveis aos casos de trabalho em condição análoga à de escravo na cadeia produtiva têxtil.

No quarto capítulo foi traçada uma síntese dos quatros casos objeto de estudo, com pesquisa qualitativa e documental que analisou a abordagem dos fatos pela ação fiscalizadora, a forma de atuação do MPT e a análise das decisões do Poder Judiciário. A pesquisa neste aspecto foi também bibliográfica, com base nas obras e estudos específicos e mais recentes sobre o trabalho escravo na cadeia produtiva têxtil. São analisadas as teorias utilizadas ao longo dos quatro casos pelo MTE, MPT e Judiciário, como a responsabilidade objetiva por ato de empregado ou preposto, a responsabilidade objetiva no Código de Defesa do Consumidor (CDC), a responsabilidade objetiva em face ao meio ambiente do trabalho (MAT), a teoria da cegueira deliberada, a teoria do empregador complexo e a teoria dos contratos coligados, além de outras citadas lateralmente.

$\mathrm{Na}$ busca por proposições que ajudem a robustecer o combate ao trabalho em condição análoga à de escravo, além dos princípios constitucionais, foram utilizadas outras fontes, como os usos e costumes internacionais e o Direito comparado, objetivando soluções que permitam a responsabilidade mais abrangente da empresa-líder, visando conferir uma maior efetividade à tutela da dignidade da pessoa humana, com a apresentação de medidas para combate ao trabalho escravo, como a alteração legislativa que contemple a aplicação da responsabilidade da empresa-líder na cadeia produtiva.

A pesquisa é interdisciplinar, permeando categorias de diversas áreas do conhecimento jurídico, como o Direito do trabalho, o Direito internacional e os direitos humanos, e é transdisciplinar por envolver incursões na Sociologia, Direito e Economia.

O método hipotético-dedutivo utilizado privilegiou a vertente jurídico-sociológica da linha crítico-metodológica. 


\section{c. Métodos e técnicas de pesquisa}

O método de procedimento específico foi a utilização da pesquisa bibliográfica, com a análise da literatura publicada através de livros, revistas, publicações avulsas e imprensa escrita, sobre o tema Trabalho em condição análoga à de escravo $e$ responsabilidade na cadeia produtiva. A pesquisa teórica se deu em bibliotecas tanto físicas como as de formato eletrônico e em órgãos públicos. Houve a análise das investigações ativas e arquivadas na base de dados do Ministério Público do Trabalho, de ações fiscais da Inspeção do Trabalho, das decisões judiciais em face de quatro varejistas renomados do setor têxtil e das convenções coletivas firmadas pelo setor da indústria têxtil na grande São Paulo, além da pesquisa documental (análise de projetos, leis, normas, resoluções, dentre outros).

Defendemos uma ressignificação da responsabilidade da empresa-líder na cadeia produtiva em que há exploração dos produtos que levam sua marca, quando constatado trabalho em condição análoga à de escravo, independentemente do título jurídico sobre as quais se estabeleceram a relação laboral, como maneira de superar a noção de indicação dos culpados para obter a responsabilidade efetiva daqueles que desenvolvem seus produtos sem observar os direitos fundamentais dos trabalhadores ativados em sua cadeia. 


\section{CONCLUSÕES}

A análise histórica demonstra que os fatos que serviram de base à formação de nossa indústria têxtil permitiram a transcendência no tempo da exploração da mão de obra. Do descobrimento do Brasil, com o trabalho escravo, até os dias atuais, com frequentes flagrantes de trabalhadores em condição análoga à de escravo, pouco se avançou no reconhecimento da dignidade humana.

Os casos analisados apontam que a teia empresarial no setor da indústria têxtil conduz à precarização do trabalho daqueles trabalhadores que se afastam da empresa-líder, ocupando lugares na ponta da produção, de modo que a ação fiscalizadora constatou trabalhadores reduzidos a condição análoga à de escravo envolvendo a cadeia produtiva de quatro grandes e reconhecidas varejistas.

Com a globalização e a reestruturação produtiva, a fragmentação da produção é acentuada pela empresa-líder, dando azo à estratégia arquitetada para reduzir custos trabalhistas e continuar produzindo as roupas com sua marca (o bem de maior valor na empresa).

Esse movimento foi o campo fértil para a proliferação de novas figuras relacionadas à gestão da produção como cadeia produtiva, cadeia de valor global, de abastecimento, suprimento, dentre outras, que confundem o operador do Direito, desviando o foco da observância do trabalho decente para o debate estéril sobre figuras econômicas que mascaram a exploração dos setores em que há a utilização mais intensiva de mão de obra, como é o da confecção de roupas.

O combate ao trabalho escravo na cadeia produtiva foi incorporado à agenda da OIT, que reafirma a necessidade de respeito aos direitos humanos, como se percebe da leitura do Protocolo $n^{\circ} 29$ da OIT, aprovado na $103^{\text {a }}$ CIT que complementa a Convenção

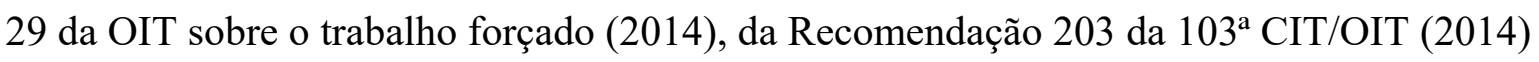
e do Relatório IV da $105^{\mathrm{a}}$ CIT, específico sobre o trabalho digno nas cadeias de abastecimento mundiais (2016). Desse modo, um combate mais efetivo impõe a adoção da premissa da OIT que trata diversas modalidades de produção como cadeia produtiva para fins laborais, para efetivar o direito ao trabalho digno, objetivo para o desenvolvimento sustentável, com base no Relatório IV da $105^{\text {a }}$ Conferência Internacional do Trabalho, visto que a diversidade de formas não pode ser obstáculo ao trabalho digno (2016, p. 1). 
Tendo como norte os normativos internacionais e os princípios constitucionais, sobretudo o da dignidade da pessoa humana, foram analisadas as teorias da responsabilidade aplicadas aos quatro casos objeto de estudo que se referem à cadeia produtiva do setor têxtil em que foram constatados trabalhadores reduzidos a condição análoga à de escravo, apresentando as abordagens utilizadas para fundamentar cada um deles.

Concluímos que é plenamente possível, como forma de robustecer a responsabilidade, a aplicação das teorias da responsabilidade objetiva pelo risco da atividade por atos de empregados e prepostos, pela cadeia produtiva à semelhança da cadeia de fornecedores do CDC e da responsabilidade objetiva pelo dano ao meio ambiente do trabalho (art. 200, VIII da CRFB c/c art. 14, § $1^{\circ}$, da Lei 6.938/81), bem como das demais citadas ao longo deste estudo como a do contrato coligado, da cegueira deliberada e do empregador complexo. Serve de reforço à responsabilização, a possibilidade de reconhecimento de solidariedade com todos os que concorreram para o danoReconhecemos que em caso de ardil, constatado o poder exercido pela varejista (detentora da marca-líder) sobre uma teia de subcontratados, pessoas físicas e jurídicas, destituídas de autonomia real e com forte subordinação estrutural, há a aplicação dos arts. $2^{\circ}, 3^{\circ}$ e $9^{\circ}$ da CLT, implicando a responsabilidade objetiva do empregador por ato de seus empregados ou prepostos (Art. 932, III do CC).

Todavia, defendemos que o desenvolvimento humano impõe a busca por soluções que superem a noção de indicação dos culpados, com uma ressignificação da responsabilidade daqueles que desenvolvem seus produtos sem observar os direitos fundamentais dos trabalhadores ativados em sua cadeia produtiva. 


\section{REFERÊNCIAS}

THE ACCORD on Fire and Building Safety in Bangladesh. Disponível em: $<$ http://bangladeshaccord.org/about/>. Acesso em: 04 nov. 2018.

AGUIAR JR., Ruy Rosado de. In: JORNADAS DE DIREITO CIVIL, 5. CJF. Anais... Organização Ruy Rosado de Aguiar Júnior. Brasília-DF: CJF, 2012. Disponível em $<$ https://www.cjf.jus.br/cjf/CEJ-Coedi/jornadas-cej/v-jornada-direitocivil/VJornadadireitocivil2012.pdf/view>. Acesso em: 12 nov. 2018.

ALENCASTRO, Luiz Felipe. O trato dos viventes. São Paulo: Companhia das Letras, 2000 .

ALESP - ASSEMBLEIA LEGISLATIVA DO ESTADO DE SÃO PAULO. CPI da ALESP. D.O.E.S.P, 14 mar. 2015.2 Disponível em $<$ http://www.al.sp.gov.br/repositorio/arquivoWeb/com/com3042.pdf $>$. Acesso em: 10 mar. 2018.

ALMEIDA, Isis de. Manual de direito processual do trabalho. 9. ed. São Paulo: LTr, 1998. p. 199.

ALONSO OLEA, Manuel. Alienación: historia de una palabra. 2. ed. México-D.F.: Universidad Autónoma de México, 1988.

. Introdução ao direito do trabalho. Coimbra: Almedina, 1965.

; CASAS BAAMONDE, María Emilia. Derecho del trabajo. 17. ed. Madrid: Civitas, 1999.

AMORIM, Elaine Regina Aguiar. No limite da precarização? terceirização e trabalho feminino na indústria de confecção. Dissertação (Mestrado em Sociologia) - Instituto de Filosofia e Ciências Humanas da Universidade Estadual de Campinas, Campinas, 2003. Disponível em: <http://repositorio.unicamp.br/jspui/handle/REPOSIP/279398>.

; JINKINGS, Isabella. Produção e desregulamentação na indústria têxtil e de confecção. In: ANTUNES, Ricardo (Org.). Riqueza e miséria do trabalho no Brasil. São Paulo: Boitempo, 2006. v. 1, p. 337-386.

ANAMATRA - ASSOCIAÇÃO NACIONAL DOS MAGISTRADOS DA JUSTIÇA DO TRABALHO. $1^{\text {a }}$ Jornada de Direito Material e Processual na Justiça do Trabalho. Enunciados aprovados. São Paulo: LTr, 2008.

ANDRADE, Shirley Silveira; BARROS, José Ivan. Trabalho escravo contemporâneo: Por que tantas absolvições? In: FIGUEIRA, Ricardo Rezende; PRADO, Adonia Antunes; GALVÃO, Edna Maria. (Orgs.) Privação de liberdade ou atentado à dignidade: escravidão contemporânea. 1. ed. Rio de Janeiro: Mauad X, 2013. p. 143-164. 
ANTUNES, Ricardo. Adeus ao trabalho? Ensaio sobre as metamorfoses e a centralidade do mundo do trabalho. São Paulo: Cortez, 2015.

. A questão do emprego no contexto da reestruturação do trabalho no final do século XX. In: HORTA, Carlos Roberto; CARVALHO, Augusto Alves. Globalização, trabalho e desemprego: um enfoque internacional. Belo Horizonte: C/Arte, 2001. p. 38-57.

. Os sentidos do trabalho: ensaios sobre a afirmação e a negação do trabalho. São Paulo: Boitempo, 2009.

APÓS denúncias de trabalho escravo, M. Officer e Marisa afirmam que roupas vinham de terceirizados. $O$ Globo, 18 jun. 2014. São Paulo. Disponível em: $<$ https://oglobo.globo.com/economia/apos-denuncias-de-trabalho-escravo-officer-marisaafirmam-que-roupas-vinham-de-terceirizados-12920768>.

ARENDT, Hannah. A condição humana. Trad. R. Raposo. 12. ed. rev. Rio de Janeiro: Forense Universitária, 2016.

ARISTÓTELES. Política. Lisboa: Veja, 1998.

ARMANDO, Eduardo. Estratégia empresarial, governança e renda em cadeias globais de valor: casos em tecnologia da informação. 2008. Tese (Doutorado em Administração) Faculdade de Economia, Administração e Contabilidade, Universidade de São Paulo, São Paulo, 2008. Disponível em: <http://www.teses.usp.br/teses/disponiveis/12/12139/tde04092008-103433/pt-br.php>.

ASSOCIAÇÃO BRASILEIRA DA INDÚSTRIA TÊXTIL- ABIT. Coletiva de Imprensa.

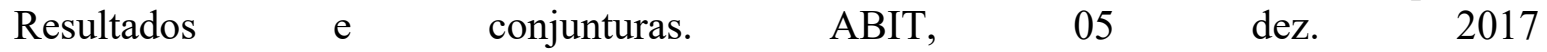
(http://www.abit.org.br/uploads/arquivos/Apresenta\%C3\%A7\%C3\%A3o\%20Coletiva\%20 de\%20Imprensa\%20-\%20VERS\%C3\%83O\%201.pdf). Acesso em: 10 jan. 2018.

ASSOCIAÇÃO do setor privado certifica empresas para eliminar o trabalho escravo de cadeias produtivas. Notícias OIT Brasília, 14 jun. 2017. Disponível em: $<$ https://www.ilo.org/brasilia/noticias/WCMS_558329/lang--pt/index.htm>. Acesso em 20 jul. 2017.

ATUALIZAÇÃO da lista suja do trabalho escravo traz 34 novos nomes. MPT Notícias, 10 abr. 2018. Disponível em: <http://portal.mpt.mp.br/wps/portal/portal_mpt/mpt/salaimprensa/mpt-noticias/9e6a438e-c338-47d9-b86c-78e1b9e8874d >. Acesso em: 10 maio 2018.

AZEVEDO, Álvaro Villaça. Teoria geral das obrigações: responsabilidade civil. 10. ed. São Paulo: Atlas, 2004.

AZEVEDO, Flávio Antônio Gomes de. A presença de trabalho forçado urbano na cidade de São Paulo: Brasil/Bolívia. 2005. Dissertação (Mestrado) - PROLAM, Universidade de São Paulo. São Paulo, 2005. 
BALDI, Mariana; VIEIRA, Marcelo Milano Falcão. Calçado do vale: imersão social e redes interorganizacionais. In: MARTES, Ana Cristina Braga. Redes e sociologia econômica. São Carlos: EdUFSCar, 2014. p. 285-308.

BALES, Kevin. Disposable people: new slavery in the global economy. Los Angeles: University of California Press, 1999.

BARAN, Paul; SWEEZY, Paul. Capitalismo monopolista. Rio de Janeiro: Zahar, 1974.

BARBOSA, Alexandre de Freitas. O mundo globalizado: política, sociedade e economia. São Paulo: Contexto, 2012.

BARROS, Alice Monteiro de. Curso de direito do trabalho. 6. ed. São Paulo: LTr, 2010.

. Trabalhadores intelectuais: subordinação jurídica. Redimensionamento. Revista de Direito do Trabalho, São Paulo, v. 30, n. 115, p. 23-42, jul./set. 2004.

BARROS, Denise Franca; COSTA, Alessandra Mello da. Consumo consciente no Brasil: um olhar introdutório sobre práticas de resistência ao consumo por meio da análise do discurso do instituto Akatu pelo consumo consciente. In: ENCONTRO DA ASSOCIAÇÃO NACIONAL DE PÓS-GRADUAÇÃO EM ADMINISTRAÇÃO, 32, Rio de Janeiro, 06-10 set. 2008. Anais... Rio de Janeiro-RJ, 2008. Disponível em: $<$ http://www.anpad.org.br/admin/pdf/MKT-A1872.pdf $>$.

; TUCCI, Flora; COSTA, Alessandra Mello da. A redenção do consumo: o caráter denegatório do 'consumo consciente'. In: ENCONTRO DE MARKETING DA ANPAD, 4. Florianópolis-SC, 23-25 maio 2010. Anais... Florianópolis-SC, 2010. Disponível em: $<$ http://www.anpad.org.br/admin/pdf/ema380.pdf $>$.

BARROSO FILHO, José. Responsabilidade civil do estado decorrente de atos judiciais. In: LEÃO, Adroaldo; PAMPLONA FILHO, Rodolfo. Responsabilidade civil. 1. ed. Rio de Janeiro: Forense, 2001.

BATALHA, Mario; SCRAMIM, Fernando Cezar Leandro. Supply chain management em cadeias agroindustriais: discussões acerca das aplicações no setor lácteo brasileiro. In: WORKSHOP BRASILEIRO DE GESTÃO DE SISTEMAS AGROALIMENTARES PENSA/FEA/USP, 2. Ribeirão Preto-SP, 1999. p. 33-44. Disponível em: $<$ https://www.researchgate.net/profile/Mario_Batalha/publication/239603009_SUPPLY_C HAIN_MANAGEMENT EM CADEIAS AGROINDUSTRIAIS DISCUSSOES A $\overline{\mathrm{CE}}$ RCA_DAS_APLICACOES_NO_SETOR_LACTEO_BRASILEIRO/links/5471c98 c0 $0 \mathrm{cf} 24$ af340c3c220/SUPPLY-CHAIN-MANAGEMENT-EM-CADEIAS-AGRO>. Acesso em: 10 ago. 2018.

BAUMAN, Zygmunt. Modernidade e Holocausto. Trad. Marcus Penchel. Rio de Janeiro: Zahar, 1998.

. Vida líquida. Trad. C. A. Medeiros. Rio de Janeiro: Zahar, 2009. 
BAUMANN, Renato. Uma visão econômica da globalização. In: BAUMANN, Renato (Ed.). O Brasil e a economia global. Rio de Janeiro: Campus, 1996. p. 33-51.

BEMERGUI, Camilla de Vilhena. O Ministério do Trabalho e Emprego na erradicação do trabalho escravo contemporâneo no Brasil: o caso da exploração do carvão vegetal. 2011. Dissertação (Mestrado em Direito) - Programa de Pós-Graduação em Direito da Faculdade de Direito da Universidade de São Paulo, São Paulo, 2011.

BIANCHI, Daniel; FECUNDINI, Gabriel Zomer; COELHO, Tatiana Durand. Crítica à tarifação discriminatória dos direitos de personalidade. In: SOUTO MAIOR, Jorge Luiz; SEVERO,Valdete Souto (Coords.). Resistência II: defesa e crítica da Justiça do Trabalho. 1. ed. São Paulo: Expressão Popular, 2018. p. 205-210.

BIGNAMI, Renato. Trabalho escravo contemporâneo: o sweating system no contexto brasileiro como expressão do trabalho forçado urbano. SINAIT, 13 dez. 2011. Disponível em:

$<$ https://www.sinait.org.br/arquivos/artigos/artigo19216c4627d24e2563a4335ceb2c9469.p df $>$. Acesso em: 15 ago. 2018.

. O tráfico de pessoas no setor têxtil. In: NOGUEIRA, Christiane V.; NOVAES, Marina; BIGNAMI, Renato (Orgs.). Tráfico de pessoas: reflexões para a compreensão do trabalho escravo contemporâneo. São Paulo: Paulinas, 2014.

BIHR, Alain. Da Grande Noite à Alternativa: o movimento operário europeu em crise. São Paulo: Boitempo, 2014.

BOXER, Charles Ralph. O império maritimo português (1415-1825). São Paulo: Companhia das Letras, 2008.

BRANDÃO, Cláudio Mascarenhas. Acidente de trabalho e responsabilidade civil do empregador. 3. ed. São Paulo: LTr, 2009.

BRASIL resgatou mais de mil trabalhadores do trabalho escravo em 2015. Governo do Brasil. Portal de Cidadania e Justiça, 2016. Disponível em: $<$ http://www.brasil.gov.br/cidadania-e-justica/2016/01/brasil-resgatou-mais-de-miltrabalhadores-do-trabalho-escravo-em-2015>. Acesso em: 10 maio 2015.

BRASIL. Decreto-Lei n ${ }^{\circ} 2.848$, de 7 de dezembro de 1940. Código Penal. Disponível em: $<$ http://www.planalto.gov.br/ccivil_03/decreto-lei/Del2848compilado.htm>. Acesso em: 12 nov. 2018.

Lei $n^{\circ} 3.353$, de 13 de maio de 1888. Declara extinta a escravidão no Brasil.

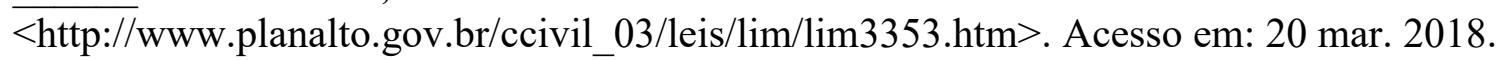

. Ministério da Fazenda. Portaria $n^{\circ}$ 92, de 12 de maio de 2003. Aprova a criação do Ponto de Contato Nacional segundo as Diretrizes para as Multinacionais - OCDE. Disponível em: <www.fazenda.gov.br/acesso-ainformacao/institucional/legislacao/portarias-ministeriais/2003/portaria92>. Acesso em: 10 set. 2018. 
BRASIL. MHD - Ministério dos Direitos Humanos. Comissão Nacional para a Erradicação do Trabalho Escravo - CONATRAE. Trabalho escravo: condenação do Brasil pela Corte Interamericana de Direitos Humanos no Caso Fazenda Brasil Verde. Brasília-DF: CONATRAE, 2017.

. MHD - Ministério dos Direitos Humanos. Pacto Federativo para a Erradicação do Trabalho Escravo. 2017. Disponível em: <http://www.mdh.gov.br/navegue-portemas/combate-ao-trabalho-escravo/pacto-federativo. Acesso em: 02 nov. 2018.

. Ministério da Justiça e Negócios Interiores. Gabinete do Ministro, 04 nov. 1940. Exposição de Motivos da Parte Especial do Código Penal. Decreto-Lei no 2.848, de 7 de dezembro de 1940 (Excertos). Disponível em: $<$ http:/honoriscausa.weebly.com/uploads/1/7/4/2/17427811/exmecp_parte_especial.pdf $>$. Acesso em: 10 mar. 2018.

MTE - Ministério do Trabalho e Emprego. Gabinete do Ministro. Portaria $N^{o}$ 1.129, de 13 de outubro de 2017. Publicada no DOU de 16/10/2017. Disponível em: $<$ http://www.in.gov.br/materia/-

/asset_publisher/Kujrw0TZC2Mb/content/id/19356195/do1-2017-10-16-portaria-n-1-129de-13-de-outubro-de-2017-19356171>. a

. MTE - Ministério do Trabalho e Emprego. Disponível em: <www.mte.gov.br/>. Acesso em: 10 maio 2018.

MTE - Ministério do Trabalho e Emprego. Instrução Normativa $n^{\circ} 139$, de 22 de janeiro de 2018. Publicada no DOU de 24/01/2018. Dispõe sobre a fiscalização para a erradicação de trabalho em condição análoga à de escravo e dá outras providências. Disponível em: $<$ http://www.trtsp.jus.br/geral/tribunal2/ORGAOS/MTE/In_Norm/IN_139_18.html>. Acesso em: 28 jan. 2018.

. MTE - Ministério do Trabalho e Emprego. Instrução Normativa da Secretaria de Inspeção do Trabalho - SIT $n^{o} 91$ de 05.10.2011. Dispõe sobre a fiscalização para a erradicação do trabalho em condição análoga à de escravo e dá outras providências. Disponível em: <http://www.normaslegais.com.br/legislacao/instrucaonormativa-sit-912011.htm>. Acesso em: 10 maio 2018.

MTE - Ministério do Trabalho e Emprego. Manual de Combate ao Trabalho em Condições Análogas às de Escravo. Brasília-DF: MTE, 2011. Disponível em: $<\mathrm{http}$ //www.mpf.mp.br/atuacao-tematica/ccr2/coordenacao/comissoes-e-grupos-detrabalho/escravidao-contemporanea-migrado-1/notas-tecnicas-planos-eoficinas/combate $\% 20$ trabalho $\% 20$ escravo $\% 20$ WEB $\% 20$ MTE.pdf $>$.

. MTE - Ministério do Trabalho e Emprego. Pernambucanas, (19 jan. 2016). Ação anulatória de AI no 0002469-03-2014-5-02-0081. Sentença. SP.

. MTE - Ministério do Trabalho e Emprego. Relatório de Ação Fiscal ZARA. São Paulo-SP, 24 de agosto de 2011. 
BRASIL. MTE - Ministério do Trabalho e Emprego. Relatório de Ação Fiscal ZARA. São Paulo-SP, 20 de abril de 2015.

. MTE - Ministério do Trabalho e Emprego. Relatório de Fiscalização Erradicação do Trabalho Escravo Pacto Contra a Precarização e Pelo Emprego e Trabalho Decente em São Paulo - Cadeia Produtiva das Confecções M5 Indústria e Comércio Ltda. - M. Officer, 2014.

. MTE - Ministério do Trabalho e Emprego. Secretaria de Inspeção do Trabalho. Trabalho escravo no Brasil em retrospectiva: referência para estudos e pesquisas. BrasíliaDF: $\quad 2012 . \quad$ Disponível em: $<$ http://portal.mte.gov.br/data/files/8A7C816A350AC882013543FDF74540AB/retrospec_t ra>. Acesso em: 15 maio 2018.

- MTE - Ministério do Trabalho e Emprego. Superintendência Regional do Trabalho e Emprego do Estado de São Paulo. Relatório de Fiscalização Erradicação do Trabalho Escravo. Pacto Contra a Precarização e pelo Emprego e Trabalho Decente em São Paulo - Cadeia Produtiva das Confecções M5 Indústria e Comércio Ltda. - M. OFFICER.

BRAVERMAN, Harry. Trabalho e capital monopolista: a degradação do trabalho no século XX. Trad. N. Caixeiro. Rio de Janeiro: LTC, 2014.

BRITO FILHO, José Claudio Monteiro de. Trabalho decente: análise jurídica da exploração do trabalho: trabalho escravo e outras formas de trabalho indigno. São Paulo: LTr, 2004.

. Trabalho escravo: caracterização jurídica. São Paulo: LTr, 2014.

- Trabalho com redução à condição análoga à de escravo: análise a partir do trabalho decente e de seu fundamento, a dignidade da pessoa humana. In: NOCCHI, Andrea Saint Pastous; VELLOSO, Gabriel Napoleão; FAVA, Marcos Neves (Coords.). Trabalho escravo contemporâneo: o desafio de superar a negação. São Paulo: LTr, 2005. p. 125-138.

BRITO, Mauricio Ferreira; DELGADO, Gabriela Neves. A transparência como medida de combate às práticas de trabalho escravo em cadeias produtivas. JOTA, 02 nov. 2018. Disponível em: <https://www.jota.info/opiniao-e-analise/artigos/a-transparencia-comomedida-de-combate-as-praticas-de-trabalho-escravo-em-cadeias-produtivas-02112018>.

Acesso em: 02 nov. 2018.

BUHMANN, Karin; JONSSON, Jonas; FISKER, Mette. " Do no harm" and "do more good" too: connecting the SDGs with business and human rights and political CSR theory". (E. P. Limited, Ed.) Corporate Governance: The international journal of business in society. Disponível em: https://doi.org/10.1108/CG-01-2018-0030. Acesso em 18.dez.2018. 
BUONFIGLIO, Maria C. Dilemas do trabalho no final do sec. XX: desemprego e precarização. In: HORTA, Carlos Roberto; CARVALHO, Ricardo Augusto Alves de (Orgs.). Globalização, trabalho e desemprego: um enfoque internacional. Belo Horizonte: C/Arte, 2001. p. 48-57.

CACCIAMALI, Maria Cristina. Entre o tráfico humano e a opção da mobilidade social: os imigrantes bolivianos na cidade de São Paulo. Cadernos PROLAM/USP, São Paulo, v. 5, n. 8, jun. 2006.

CALDAS, Renata Theophilo. O trabalho escravo na cadeia produtiva das renomadas grifes da indústria da moda. Brasília-DF: IDP/EDB, 2017.

CALDEIRA, João Paulo. Levantamento traz lista de marcas de roupas flagradas com trabalho escravo. Jornal GGN, 23 jun. 2016. Disponível em: $<$ https://jornalggn.com.br/noticia/levantamento-traz-lista-de-marcas-de-roupas-flagradascom-trabalho-escravo>. Acesso em: 23 maio 2017.

CALLEGARI, José Carlos. Uma releitura da subordinação. 2012. Dissertação (Mestrado em Direito) - Programa de Pós-Graduação em Direito daFaculdade de Direito da Universidade de São Paulo, São Paulo, 2012.

CAPEZ, Fernando. Curso de direito penal: parte especial. 9. ed. São Paulo: Saraiva, 2009. v. 2.

CARDOSO, Lys Sobral; RIBEIRO JR., Raymundo Lima. Da responsabilidade solidária da cadeia econômica pela exploração do trabalho infantil. Revista do Ministério Público do Trabalho, ano 24, n. 47, p. 285-306, mar. 2014.

CARELLI, Rodrigo de Lacerda. Terceirização e intermediação de mão-de-obra. Rio de Janeiro: Renovar, 2003.

CARVALHO, Carlos Miguel Delgado de. Geographia humana: política e econômica. São Paulo: Companhia Ed. Nacional, 1935.

CARVALHO, José Murilo de. Os bestializados: o Rio de Janeiro e a república que não foi. São Paulo: Companhia das Letras, 2007.

CARVAlHO, Laura; MÁXIMO, Fabrício; ALVES, Pedro Daniel Blanco. O trabalho temporário na "reforma" trabalhista. In: SOUTO MAIOR, Jorge Luiz; SEVERO, Valdete Souto (Coords.). Resistência: aportes teóricos contra o retrocesso trabalhista. São Paulo: Expressão Popular, 2017. p. 105-112.

CARVALHO, Ricardo Augusto Alves de. A. Reconfiguração de perfis entre os processos de inserção, 'desinserção' e reinserção dos (novos) sujeitos trabalhadores. In: HORTA, Carlos Roberto; CARVALHO, Ricardo Augusto Alves de (Orgs.). Globalização, trabalho e desemprego: um enfoque internacional. Belo Horizonte: C/Arte, 2001. p. 149-165. 
CASAldÁligA, Pedro (Bispo). Carta Pastoral - "Uma Igreja da Amazônia em Conflito com o Latifúndio e a Marginalização Social" - é considerado o primeiro texto público sobre trabalhadores submetidos ao trabalho em condição análoga à de escravo. Comissão Pastoral da Terra, [s.d.]. Disponível em: <www.cptnacional.org.br>. Acesso em: 10 maio 2017.

(Bispo). Uma Igreja da Amazônia em conflito com o latifúndio e a marginalização social. São Félix do Araguaia, 10 de outubro de 1971. Disponível em: $<$ http://servicioskoinonia.org/Casaldaliga/cartas/1971CartaPastoral.pdf $>$. Acesso em: 10 jan. 2018.

CASTEL, Robert. As metamorfoses da questão social: uma crônica do salário. 9. ed. Rio de Janeiro: Vozes, 2010.

CASTELLS, Manuel. A sociedade em rede: a era da informação: economia, sociedade e cultura. Trad. Roneide Venâncio Majer. São Paulo: Paz e Terra, 2009. v. 1.

CASTILHO, Ela Wiecko Volkmer de. Trabalho forçado e trabalho escravo no direito penal brasileiro. Florianópolis: UFSCAR, 1994.

CAVAlCANTI, Tiago Muniz. Neoabolicionismo \& direitos fundamentais. São Paulo: LTr, 2016.

- O trabalho escravo entre a arte e a realidade: a necessária superação da perspectiva hollywoodiana. Revista do Tribunal Superior do Trabalho, Rio de Janeiro, v. 81, n. 2, p. 207-222, abr./jun. 2015.

CAVALIERI FILHO, Sergio. Programa de responsabilidade civil. 5. rev. aum. e atual de acordo com o Novo CC. São Paulo: Malheiros Ed., 2004.

. Programa de responsabilidade civil. São Paulo: Malheiros Ed., 2006.

CESARINO JR., A. F. Direito social brasileiro. 4. ed. São Paulo: Freitas Bastos, 1957. v. 1.

CHESNAIS, François. A mundialização do capital. Trad. Silvana Finzi Foá. Rio de Janeiro: Xamã, 1996.

CHOI, Keum Joa. Além do arco-íris: a migração coreana no Brasil. 1991. Dissertação (Mestrado em História Social) - Faculdade de Filosofia, Letras e Ciências Humanas da Universidade de São Paulo, São Paulo, 1991.

. Imigração coreana na Cidade de São Paulo. Revista do Instituto de Estudos Brasileiros, São Paulo, v. 40, p. 233-238, 1996. Disponível em: $<$ http://www.revistas.usp.br/rieb/issue/view/5659>. Acesso em: 10 jan. 2017.

CMSP - CÂMARA MUNICIPAL DE SÃO PAULO. Relatório Final da Comissão Parlamentar de Inquérito para Apurar a Exploração de Trabalho Análogo ao de Escravo. Processo 0024/2005. Câmara Municipal de São Paulo, fev. 2005. Disponível em: $<$ http://www.justica.sp.gov.br/StaticFiles/SJDC/ArquivosComuns/ProgramasProjetos/NET P/CPI\%20do\%20trabalho\%20escravo.pdf>. Acesso em: 10 mar. 2018. 
CODORVIL, Fabíola Castelo de Souza. A situação as indústrias domésticas das redes de subcontratação têxteis no espaço urbano e microrregional de Tubarão-SC. 2001. Dissertação (Mestrado em Geografia) - Centro de Filosofia e Ciências Humanas da Universidade de Santa Catarina Universidade, Florianópolis-SC, 2001.

COE, Neil M.; HESS, Martin. Global production networks: debates and challenges. Paper prepared for the GPERG Workshop on Global Production Networks, Manchester, 25-26 Jan. 2007. Manchester: University of Manchester, 2007.

COLLI, Juliana Marília. A trama da terceirização: um estudo do trabalho no ramo da tecelagem Campinas-SP: Ed. da Unicamp, 2000.

COMISSÃO SINDICAL CONSULTIVA DA OCDE - TUAC - Trade Union Advisory Committee. Diretrizes da OCDE para as Empresas Multinacionais: recomendações para uma conduta comercial responsável num contexto global. Guia dos sindicatos. TUAC Trade Union Advisory Committee), 2015. Disponível em: $<$ http://www.tuacoecdmneguidelines.org/Docs/TradeUnionGuide_Port.pdf $>$. Acesso em: 10 jul. 2018.

COMPLIANCE. In: CAMBRIDGE Dictionary [s.d.]. Cambridge University Press. Disponível em: $\quad<$ https://dictionary.cambridge.org/pt/dicionario/inglesportugues/compliance>. Acesso em: 10 maio 2018.

CONDENADA por trabalho escravo, M.Officer pode ser proibida de vender em SP por 10 anos. MPT Notícias, 08 nov. 2017. Disponível em: $<$ https://mpt.jusbrasil.com.br/noticias/518465695/condenada-por-trabalho-escravo-mofficer-pode-ser-proibida-de-vender-em-sp-por-10-anos>. Acesso em: 08 dez. 2017.

CONSELHO DA EUROPA. Convenção Europeia dos Direitos do Homem. StrasbourgFR, 1950. Em vigor em 3 set. 1953. Disponível em: $<$ http://www.refugiados.net/cid_virtual_bkup/asilo1/cesdh.html $>$. Acesso em: 10 set. 2018.

CONTINO, Joana Martins. O fast fashion e a condição pós-moderna. In: COLÓQUIO DE MODA INTERNACIONAL, 8. EDIÇÃO INTERNACIONAL, 5. Rio de Janeiro-RJ, 2012. Disponível em: <http://www.coloquiomoda.com.br/anais/8>. Acesso em: 25 ago. 2018.

COOPER, Frederick; HOLT, Thomas C.; SCOTT, Rebecca J. Além da escravidão: investigação sobre raça, trabalho e cidadania em sociedades pós-emancipação. Trad. M. B. Medina. Rio de Janeiro: Civilização Brasileira, 2005.

CORIAT, Benjamin. Pensar pelo avesso: o modelo japonês de trabalho e organização. Tradução de Emerson S. da Silva. Rio de Janeiro: Revan, 1994.

COSTA, Achyles Barcelos da; CONTE, Nelton Carlos; CONTE, Valquiria Carbonera. A China na cadeia têxtil - vestuário: impactos após a abertura do comércio brasileiro ao mercado mundial e do final dos Acordos Multifibras (AMV) e Têxtil Vestuário (ATV). Revista Teoria e Evidência Econômica, ano 19, n. 40, p. 11-15, jan./jun. 2013. Disponível em: <http://seer.upf.br/index.php/rtee/article/view/3442/2280>. 
COSTA, Ana Cristina Rodrigues da; ROCHA, Érico Rial Pinto da. Panorama da cadeia produtiva têxtil e de confecções e a questão da inovação. BNDES Setorial, Rio de Janeiro, n. 29, p. 159-208, mar. 2009.

COSTA, Ângelo Fabiano Farias da; MONTEIRO, Ana Cláudia Rodrigues Bandeira; BELTRAMELLI NETO, Sílvio (Coords.). Reforma trabalhista na visão dos Procuradores do Trabalho. Salvador: Juspodivm, 2018.

COSTA, Luís Cesar; MELLO, Leonel Itaussu. História do Brasil. São Paulo: Scipione, 1999.

COSTA, Marcelo Freire Sampaio. Primeiras impressões sobre o impacto da reforma trabalhista no instituto do dano moral coletivo nas relações laborais. In: COSTA, Ângelo Fabiano Farias da; MONTEIRO, Ana Cláudia Rodrigues Bandeira; BELTRAMELLI NETO, Sílvio (Coords.). Reforma trabalhista na visão dos Procuradores do Trabalho. Salvador: Juspodivm, 2018. p. 291-308.

COUTINHO, Grijalbo Fernandes. Terceirização: máquina de moer gente trabalhadora. São Paulo: LTr, 2015.

CYMBALISTA, Renato; XAVIER, Iara Rolnik. A comunidade boliviana em São Paulo: definindo padrões de territorialidade. Cadernos Metrópole, n. 17, p. 119-133, 2007.

DALLEGRAVE NETO, José Affonso. Responsabilidade civil no direito do trabalho. 3. ed. São Paulo: LTr, 2008.

DAL-ROSSO, Sadi. Mais trabalho! a intensificação do labor na sociedade contemporânea. São Paulo: Boitempo, 2008.

DAVATZ, Thomas. Memórias de um colono no Brasil (1850). Trad. S. B. Holanda. São Paulo: Ed. da Universidade de São Paulo, 1980. v. 11.

DE PAGE, Henri. À propos du governement des juges. Paris: Sirey, 1931.

DECLARAÇÃO dos Direitos do Homem e do Cidadão de 1789. Disponível em: $<$ http://pfdc.pgr.mpf.mp.br/atuacao-e-conteudos-de-apoio/legislacao/direitoshumanos/declar_dir_homem_cidadao.pdf >. Acesso em: 25 ago. 2018.

DEDDECA, Cláudio Salvadori. Racionalização econômica e trabalho no capitalismo avançado. Campinas-SP: Instituto de Economia da Unicamp, 1999.

DELGADO, Gabriela Neves. Terceirização: paradoxo do direito do trabalho contemporâneo. São Paulo: 2003.

DELGADO, José Augusto. Cláusulas gerais e conceitos indeterminados: CC e CF. In: ALVIM, Arruda; CÉSAR, Joaquim Portes de Cerqueira; ROSAS, Roberto (Coords.). Aspectos controvertidos do novo Código Civil: escritos em homenagem ao Ministro José Carlos Moreira Alves. São Paulo: Revista dos Tribunais, 2003. 
DELGADO, Mauricio Godinho. Capitalismo, trabalho e emprego: entre o paradigma da destruição e os caminhos da reconstrução. São Paulo: LTr, 2006b.

. Curso de direito do trabalho. 14. ed. São Paulo: LTr, 2015.

. Direitos fundamentais na relação de trabalho. Revista LTr, São Paulo, v. 70, n. 6, p. 657-667, jun. 2006a.

. O poder empregatício. São Paulo: LTr, 1996.

; DELGADO, Gabriela Neves. A reforma trabalhista no Brasil: com os comentários à Lei no 3.467/2017. São Paulo: LTr, 2017.

DEMARCHI, André; MORAIS, Odilon. Mais algumas ideias equivocadas sobre os índios ou o que não deve mais ser dito sobre eles. Projeto de Pesquisa. Universidade Federal do Tocantins, 2015.

DESABAMENTO em Bangladesh revela lado obscuro da indústria de roupas. BBC Brasil, 28 abr. 2013. Disponível em: $<$ https://www.bbc.com/portuguese/noticias/2013/04/130428_bangladesh_tragedia_lado_ob scuro $>$. Acesso em: 10 abr. 2016.

DIAS, José de Aguiar. Da responsabilidade civil. 10 ed. Rio de Janeiro: Forense, 1995. v. 1.

DICKEN, Peter. Mudança global: mapeando as novas fronteiras da economia global. Trad. T. C. Souza. 5. ed. Porto Alegre: Bookman, 2010.

DOCA, Geralda; COUTINHO, Mateus; SORIMA NETO, João; CAVALCANTI, Glauce. Bolsonaro confirma que Ministério do Trabalho vai acabar. O Globo, 14 nov. 2018. Disponível em: <https://oglobo.globo.com/economia/bolsonaro-confirma-que-ministeriodo-trabalho-vai-acabar-23217868> . Acesso em: 07 nov. 2018.

DRUCK, Graça. O avanço da terceirização do trabalho: principais tendências nos últimos 20 anos no Brasil e na Bahia. Bahia: Análise \& Dados, Salvador, v. 21, n. 2, p. 399-416, abr./jun. 2011.

; BORGES, Ângela. Terceirização: balanço de uma década. Caderno $C R H$, Salvador, n. 37, p. 111-139, jul./dez. 2002. Disponível em: https://repositorio.ufba.br/ri/bitstream/ri/2490/1/RCRH-2006-132\%5b1\%5d\%20S.pdf>.

; FRANCO, Tânia. Trabalho e precarização social. Caderno CRH, Salvador v. 24, n. $\quad$ esp. 1, p. 9-13, 2011. Disponível em: $<$ http://www.scielo.br/pdf/ccrh/v24nspe1/a01v24nspe1.pdf $>$.

EBERT, Paulo Roberto Lemgruber. Da saúde e da segurança no trabalho ao meio ambiente do trabalho: a construção de um novo paradigma. In: SOUTO MAIOR, Jorge Luiz; SEVERO,Valdete Souto (Coords.). Resistência II: defesa e crítica da Justiça do Trabalho. 1. ed. São Paulo: Expressão Popular, 2018. p. 191-198. 
EM 20 anos, 50 mil trabalhadores foram resgatados do trabalho escravo no Brasil. $I G, 13$ maio 2015. Disponível em: <http://economia.ig.com.br/2015-05-13/em-20-anos-50-miltrabalhadores-foram-resgatados-de-trabalho-escravo-no-brasil >. Acesso em: 10 maio 2017.

EMPRESAS do mundo todo têm ignorado obrigações de direitos humanos, dizem relatores da ONU. ONUBR. Nações Unidas do Brasil, 16 out. 2018. Disponível em: $<$ https://nacoesunidas.org/empresas-do-mundo-todo-tem-ignorado-obrigacoes-de-direitoshumanos-dizem-relatores-da-onu/> . Acesso em: 18 out. 2018.

ENEI, José Virgílio Lopes. Contratos coligados. Revista de Direito Mercantil, Industrial, Econômico e Financeiro, São Paulo, v. 42, n. 132, p. 111-128, out./dez. 2003.

ENUNCIADO 421. In: JORNADAS DE DIREITO CIVIL, 5. CJF. Organização Ruy Rosado de Aguiar Júnior. Anais... Brasília-DF: CJF, 2012. p. 71. Disponível em $<$ https://www.cjf.jus.br/cjf/CEJ-Coedi/jornadas-cej/v-jornada-direitocivil/VJornadadireitocivil2012.pdf/view>. Acesso em: 12 nov. 2018

ERMIDA URIARTE, Oscar. Deslocalización, globalización y derecho del trabajo. IUSLabor, n. 1, p. 1-17, 2007. Disponível em: $<$ https://www.raco.cat/index.php/IUSLabor/article/view/5794>. Acesso em 10.dez.2018.

1981.

. Empresas multinacionales y derecho laboral. Montevideo: Amalio Fernández,

ESPECIAL Zara: flagrantes de escravidão na produção de roupas de luxo. Repórter Brasil, 20 dez. 2011. Disponível em: <https://reporterbrasil.org.br/2011/12/especial-zaraflagrantes-de-escravidao-na-producao-de-roupas-de-luxo/>. Acesso em: 20 dez. 2017.

ESTUDOS apresentam perfil do Microempreendedor Individual. SEBRAE. Disponível em: $<$ https://m.sebrae.com.br/sites/PortalSebrae/estudos_pesquisas/estudos-apresentam-perfildo-microempreendedorindividualdetalhe6,6a1713074c0a3410VgnVCM1000003b74010aRCRD>. Acesso em: 10 jun. 2017.

EUROPEAN COMISSION. Directorate-General for Employment, Social Affairs and Inclusion. Transformation of labour and future of labour law in Europe. European Comission. Final report. (Published: 1999-07-13). Luxembourg: Office for Official Publications Communities, 1999. Disponível em: $<$ https://publications.europa.eu/en/publication-detail/-/publication/b4ce8f90-2b1b-43eca1 ac-f857b393906e>. Acesso em: 05 dez. 2018.

"EXISTE trabalho escravo na moda. E aí, você vai compactuar?", diz Astrid Fontenelle. Debates e exposição interativa promovidos pelo MPT para sensibilizar a sociedade acontecem até amanhã (23) na capital paulista, durante semana da moda. MPT Notícias, 22 out. 2018. Disponível em: <http://portal.mpt.mp.br/wps/portal/portal_mpt/mpt/salaimprensa/mpt-noticias/7db92971-b262-4519-bb3d-62a555faaec1>. Acesso em 29 out. 2018. 
FABRE, Luiz. Novos institutos relacionados ao tráfico de pessoas no setor têxtil: o princípio do non-revoulement e a teoria da cegueira deliberada. Revista do Ministério Público do Trabalho, Brasília, ano 22, n. 44, p. 44-61, set. 2012.

FARIA, José Eduardo. Democracia e governabilidade: os direitos humanos à luz da globalização econômica. In: FARIA, José Eduardo (Org.). Direito e globalização econômica: implicações e perspectiva. São Paulo: Malheiros Ed., 2010. p. 127-160.

. O direito na economia globalizada. São Paulo: Malheiros Ed., 1992.

FAUSTO, Boris. História concisa do Brasil. São Paulo: Edusp, 2002.

FAVARETTO, Júlia Spiguel. Imigrações internacionais contemporâneas: o caso dos bolivianos em São Paulo. In: SIMPÓSIO NACIONAL DE HISTÓRIA, ANPUH, 26., São Paulo. Anais... 2011. Disponível em: $<$ http://www.snh2011.anpuh.org/resources/anais/14/1300846171_ARQUIVO_textoanpuh1 .pdf $>$. Acesso em: 10 jul. 2018.

FEDERICI, Silvia. Calibã e a bruxa. Trad. C. Sycorax. São Paulo: Elefante, 2017.

FELICIANO, Guilherme Guimarães. Curso crítico de direito do trabalho. São Paulo: Saraiva, 2013a.

. O meio ambiente do trabalho e a responsabilidade civil patronal - reconhecendo a danosidade sistêmica. In: FELICIANO, Guilherme Guimarães; URIAS, João; MARANHÃO, Ney; SEVERO, Valdere Souto (Coords.). Direito ambiental do trabalho: apontamentos para uma teoria geral. São Paulo: LTr, 2013b. v. 1, p. 11-26.

. Tópicos avançados de direito material do trabalho: atualidades forenses. São Paulo: Damásio de Jesus, 2006.

FERRARI, Irany; NASCIMENTO, Amauri Mascaro; SILVA, Ives Gandra. História do trabalho, do direito do trabalho e da Justiça do Trabalho. São Paulo: LTr, 1998.

FERRAZ, João Carlos; KUPFER, David S.; HAGUENAUER, Lia. Made in Brazil: desafios competitivos para a indústria. Rio de Janeiro: Campus, 1995.

FIGUEIRA, Ricardo Rezende. Pisando fora da própria sombra: a escravidão por dívida no Brasil contemporâneo. Rio de Janeiro: Civilização Brasileira, 2004.

FILGUEIRAS, Vitor Araújo. Terceirização e trabalho análogo ao escravo: coincidência? Grupo de pesquisa Indicadores de Regulação do Emprego, vinculado à Universidade Estadual de Campinas (UNICAMP), 2013. Disponível em: $<$ https://indicadoresdeemprego.files.wordpress.com/2013/12/tercerizac3a7c3a3o-etrabalho-anc3a1logo-ao-escravo1.pdf>. Acesso em: 04 jun. 2018.

; CAVALCANTE, Sávio Machado. Terceirização: um problema conceitual e político. Le Monde Diplomatique Brasil, ed. 90, 06 jan. 2015. Disponível em: $<$ https://diplomatique.org.br/terceirizacao-um-problema-conceitual-e-politico/>. Acesso em: 04 jun. 2018. 
FILGUEIRAS, Vitor Araújo; SALES, Jeane. Trabalho análogo ao escravo no Brasil: natureza do fenômeno e regulação. Revista da ABET, v. 12, n. 2, p. 29-47, jan./jun. 2018. Disponível

em: $<$ http://www.periodicos.ufpb.br/ojs/index.php/abet/article/download/20206/11213>. Acesso em: 10 mar. 2018.

FINLEY, Moses I. Escravidão antiga e ideologia moderna. Trad. N. L. Guarinello. Rio de Janeiro: Graal, 1991.

FIORILlO, Celso Antonio Pacheco. Curso de direito ambiental brasileiro. São Paulo: Saraiva, 2002.

FLEURY, Paulo Fernando. Supply chain management: conceitos, oportunidades e desafios da implementação. Revista Tecnologística, v. 4, n. 30, p. 25-32, fev. 1999. Disponível em: $<$ http://professorricardo.tripod.com/Artigo_15.pdf $>$. Acesso em: 05 maio 2017.

FRANCO, Maria Sylvia Carvalho. Organização social do trabalho no período colonial. Discurso, São Paulo, n. 8, p. 1-45, 09 jun. 1978. Disponível em: $<$ http://www.revistas.usp.br/discurso/article/view/37832/40559>.

FREIRE, Claudia. Reconfigurações do trabalho na produção fabril de confecções no Agreste de Pernambuco. In: ENCONTRO NACIONAL DA ABET, 15., 06-09 set. 2017, Rio de Janeiro. Anais... Rio de Janeiro; ABET, 2017. p. 1-15.

FREITAS, Juarez. As grandes linhas da filosofia do direito. Caxias do Sul-RS: UCS, 1986.

FRINHANI, Fernanda de Magalhães Dias. As representações sociais dos profissionais do direito sobre tráfico de pessoas. 2014. Tese (Doutorado) - Programa de Pós-Graduação em Direito da Faculdade de Direito da Universidade de São Paulo, São Paulo, 2014.

FURTADO, João. Cadeias produtivas globalizadas: a emergência de um sistema de produção integrado hierarquicamente no plano internacional. In: FURTADO, João (Org.). Globalização das cadeias produtivas no Brasil. 1. ed. São Carlos-SP: EDUFScar, 2003. p. 15-38. 2003.

(Org.). Globalização das cadeias produtivas no Brasil. São Carlos-SP: EDUFScar,

GALDINO, Dirceu; LOPES, Aparecido Domingos Errerias. Manual de direito do trabalho rural. 2. ed. São Paulo: LTr, 1993.

GALEANO, Eduardo. As veias abertas da América Latina. Trad. S. Faraco. Porto Alegre: L\&PM, 2017.

GARCIA JR., Afrânio Raul. Libertos e sujeitos: sobre a transição para trabalhadores livres do Nordeste. Revista Brasileira de Ciências Sociais, RBCS, Associação Nacional de PósGraduação e Pesquisa em Ciências Sociais, v. 7, n. 3, p. 120, jun. 1988. Disponível em: $<$ http://www.anpocs.org.br/portal/publicacoes/rbcs_00_07/rbcs07_01.htm>. Acesso em: 10 jul. 2018. 
GAUDÉRIO, Antônio. O preço de um vestido. Folha de S. Paulo, São Paulo, 16 dez. 2007. Disponível em: <https://www1.folha.uol.com.br/fsp/dinheiro/fi1612200711.htm>. Acesso em: 05 nov. 2018.

GEFFRAY, Christian. Chroniques de la servitude en Amazonie brésilienne: essai sur l'xplotation paternaliste. Paris: Karthala, 1995.

GEREFFI, Gary. Competitividade e redes na cadeia produtiva do vestuário na América do Norte. Revista Latinoamericana de Estudios del Trabajo, v. 3, n. 6, p. 101-127, 1997.

. Competitividade e redes na cadeia produtiva do vestuário na América do Norte.

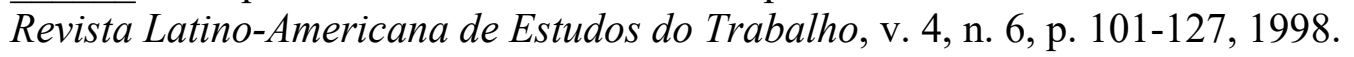

GOMES, Luiz Roldão De Freitas. Elementos de responsabilidade civil. Rio de Janeiro: Renovar, 2000.

GONÇALVES, Carlos Roberto. Responsabilidade civil. 7. ed. São Paulo: Saraiva, 2002.

GONDIM, Andrea da Rocha Carvalho. Os enunciados da $2^{\mathrm{a}}$ Jornada de Direito do Trabalho e a Atividade Interpretativa do Magistrado. Blog do Rodrigo Carelli. Rio de Janeiro, 23 out. 2017. Disponível em: <https://rodrigocarelli.org/2017/10/23/osenunciados-da-2a-jornada-de-direito-do-trabalho-e-a-atividade-interpretativa-domagistrado-andrea-gondim-artigos-de-outros-autores/>. Acesso em: 15 maio 2018.

A responsabilidade por danos labor-ambientais no setor automobilístico. In: FELICIANO, Guilherme Guimarães; EBERT, Paulo Roberto Lemgruber (Coords.). Direito ambiental do trabalho: apontamentos para uma teoria geral. São Paulo: LTr, 2018. p. 177-188.

; SANTOS, Ronaldo Lima dos. O tráfico de pessoas e a atuação do Ministério Público do Trabalho. In: CAVALCANTI, Tiago Muniz; PAIXÃO, Cristiano (Orgs.). Combate ao trabalho escravo: conquistas estratégias e desafios: homenagem aos 15 anos da Conaete. São Paulo: LTr, 2017. p. 251-271.

GORENDER, Jacob. A escravidão reabilitada. São Paulo: Expressão Popular, 2016.

O escravismo colonial. 6. ed. São Paulo: Expressão Popular, 2016.

Globalização, tecnologia e relações de trabalho. Estudos Avançados, São Paulo, v. 9, n. 25, p. 311-361, abr. 1997. Disponível em: $<$ http://www.scielo.br/scielo.php?script=sci_arttext\&pid=S0103-

$40141997000100017 \& \operatorname{lng}=$ pt\&nrm=iso $>$. Acesso em 23 nov. 2017.

GORINI, Ana Paula. Panorama do setor têxtil no Brasil e no mundo: reestruturação e perspectivas. BNDES Setorial, p. 17-50, set. 2000.

GOSFOGUEL, Ramón. Para descolonizar os estudos de economia política e os estudos pós-coloniais: transmodernidade, pensamento de fronteira e colonialidade global. Tradução de Inês Martins Ferreira. Revista Crítica de Ciências Sociais, n. 80, p. 115-147, 2008. Disponível em: <https://journals.openedition.org/rccs/pdf/697>. 
GRAMSCI, Antônio. Americanismo e fordismo. Trad. G. Bogossian. São Paulo: Hedra, 2008.

GRINBERG, K.; PEABODY, S. Escravidão e liberdade nas Américas. Rio de Janeiro: FGV, 2013.

GUIMARÃES, Priscilla de Brito Ataíde. A imigração e a proteção do trabalho: o dilema entre aplicação do Estatuto do Estrangeiro e a proteção trabalhista dos imigrantes bolivianos e haitianos. São Paulo: LTr, 2016.

GUIMARÃES, Rogério de Almeida Pinto. Fundamentos da responsabilidade solidária das empresas da cadeia produtiva nas violações ao direito do trabalho. 2018. Monografia (Especialização em Direito Público Aplicado ao Ministério Público do Trabalho) - Escola Superior do Ministério Público da União, ESMPU, Brasília-DF, 2018.

HARVEY, David. A condição pós-moderna. Trad. Adail Ubirajara Sobral e Maria Stela Gonçalves. 17. ed. São Paulo: Edições Loyola, 1992.

2016.

. 17 Contradições e o fim do capitalismo. Trad. R. Bettoni. São Paulo: Boitempo, . Para entender o Capital: Livro I. Trad. R. Enderle. São Paulo: Boitempo, 2013.

HASHIZUME, Maurício. Escravidão é flagrada em oficina de costura ligada à Marisa. Repórter Brasil, 17 mar. 2010. Disponível em: $<$ https://reporterbrasil.org.br/2010/03/escravidao-e-flagrada-em-oficina-de-costura-ligadaa-marisa/>. Acesso em: 06 maio 2016.

HEMINGWAY, Ernest. Por quem os sinos dobram? 11. ed. Trad. L. Peazê. Rio de Janeiro: Bertrand Brasil, 2012.

HENDERSON, Jeffrey; YEUNG, Henry Wai-Chung; DICKEN, Peter; HESS, Matin; COE, Neil. Global production networks and the analysis of economic development. Review of Internacional Political Economy, v. 9 n. 3, p. 436-464, Aug. 2002. Disponível em: $<$ https://courses.nus.edu.sg/course/geoywc/publication/2002_ripe.pdf $>$. Acesso em: maio 2018.

HUBERMAN, Leo. História da riqueza do homem. Rio de Janeiro: LTC, 2016.

HUNGRIA, Nelson. Comentários ao Código Penal. Rio de Janeiro: Forense, 1958. v. 6.

IANNI, Octavio. A era do globalismo. Rio de Janeiro: Civilização Brasileira, 1996.

. Teorias da globalização. Rio de Janeiro: Civilização Brasileira, 1999.

ILO - INTERNATIONAL LABOUR ORGANIZATION. (10-12 Dec. 2013). Meeting of Experts on Labour Inspection and the Role of Private Compliance Initiatives. International Labour Office, Geneva, Switzerland, 10-12 Dec. 2013. 
INFORMATIVO do STF, Brasília, n. 688, 12-16 nov. 2012. Disponível em http://www.stf.jus.br/arquivo/informativo/documento/informativo688.htm>. Acesso em: 10 mar. 2018.

INNERARITY, Daniel. Un monde désynchronisé. Temps: science, arts, philosophie, n. 2, p. 29-38, juin. 2014.

INTEGRIDADE e ética nos negócios. Rede Brasil Pacto Global, 08 dez. 2015. Disponível em: <http://pactoglobal.org.br/integridade-e-etica-nos-negocios/>. Acesso em: 10 ago. 2018.

JOLY, Fábio Duarte. Escravidão na Roma Antiga. 2. ed. São Paulo: Alameda, 2017.

Libertate opus est. escravidão, manumissão e cidadania à época de Nero (54-68 d.C.). 2006. (Doutorado em História Econômica) - Faculdade de Filosofia, Letras e Ciências Humanas da Universidade de São Paulo, São Paulo, 2006.

KANT, Immanuel. Fundamentação da metafísica dos costumes. Trad. P. Quintela. Lisboa: Edições 70, 2003.

KAPLINSKY, Raphael; MORRIS, Mike. A handbook for value chain research. Sussex: University of Sussex, Institute of Development Studies, 2000. v. 113. Disponível em: $<$ www.ids.ac.uk/ids/global/pdfs/VchNov01.pdf>. Acesso em: 05 jun. 2017.

KLEIN, Naomi. Sem logo: a tirania das marcas em um planeta vendido. 2. ed. Tra. (R. Vinagre, Trad.) Rio de Janeiro: Record, 2002.

KOK, Gloria Porto. A escravidão no Brasil colonial. 7. ed. São Paulo: Saraiva, 2012.

KORZENIEWICZ, Miguel; GEREFFI, Gary (Eds.). Commodity chains and global capitalism. Praeger: Westport, 1994.

KREIN, José Dari. O aprofundamento da flexibilização das relações de trabalho no Brasil nos anos 90. 2001. Campinas-SP, 2001.

- O capitalismo contemporâneo e a saúde do trabalhador. Revista Brasileira de Saúde Ocupacional, São Paulo, v. 38, n. 128, p. 194-196, 2013. Disponível em: $<$ http://www.scielo.br/pdf/rbso/v38n128/07.pdf $>$.

KROST, Oscar. O lado avesso da reestruturação produtiva: a 'terceirização' de serviços por facções. Blumenau-SC: Nova Letra, 2016.

LAZO, Albino Ruiz. O mundo é amplo e alheio: dos Andes a São Paulo. Braudel Papers, 28, p. 3-16, 2001. Disponível em: <http://pt.braudel.org.br/publicacoes/braudelpapers/28.php>. Acesso em: 08 dez. 2018.

LEAL JÚNIOR, João Carlos; MARTINS, Pedro Henrique Machado. Responsabilidade civil do emrpegador no pré-contrato de trabalho. Revista de Direito em (Dis)Curso, Londrina, v. 4, n. 1, p. 25-47, jan./jul. 2011. Disponível em: $<$ http://www.uel.br/revistas/uel/index.php/rdd/article/download/10509/12437>. 
LEÃO, Luís Henrique da Costa; VASCONCELOS, Luiz Carlos Fadel de. Nas trilhas das cadeias produtivas: reflexôes sobre uma política integradora de vigiância em saúde, trabalho e ambiente. Revista Brasileira de Saúde Ocupacional (RBSO), São Paulo, v. 38, n. 127, p. 107-121, 2013. Disponível em: $<$ http://www.scielo.br/pdf/rbso/v38n127/v38n127a13.pdf $>$.

LEITE, Carlos Henrique Pereira. Instrumentos de atuação do Ministério Público do Trabalho para a responsabilização solidária pelas infrações ao meio ambiente de trabalho na cadeia produtiva da carnaúba. Dissertação (Mestrado) - Universidade Católica de Brasília, Brasília, 2017.

LENCIONI, Sandra. A reestruturação da Indústria Têxtil no Estado de São Paulo. Revista do Departamento de Geografia (USP), v. 10, p. 79-90, 1996. Disponível em: $<$ http://www.revistas.usp.br/rdg/article/view/53706/57669>.

LIMA, Alvino. Culpa e risco. 2. rev. e atual. São Paulo: Revista dos Tribunais, 1998.

LIMA, Flávio Ribeiro de. Nas trilhas da exploração da força de trabalho: uma análise a partir da cadeia têxtil de produção no Noroeste do Estado do Paraná. 1998. Dissertação (Mestrado) - Universidade Federal do Paraná. Setor de Ciências da Terra. Programa de Pós-Graduação em Geografia, Curitiba, 2018.

LIMA, Jacob. Mobilidade do capital e do trabalho: redes, espacialidades e precariedades na indústria do vestuário. In: PERALVA, Angelina; TELLES, Vera da Silva (Orgs.). Ilegalismos na globalização: trabalho, migrações, mercados Rio de Janeiro: Ed. UFRJ, 2015. p. 156-170.

LOMBARDI, Laci. Os reflexos da reestruturação industrial têxtil em Blumenau/SC. In: THEIS, Ivo M. (Org.). Desenvolvimento local/regional na periferia do capitalismo mundializado: estudos de casos em Santa Catarina. Blumenau: Edfurb, 2014. p. 89-106.

LOPES, Cristiane Maria Sbalqueiro. Direito de imigração: o estatuto do estrangeiro em uma perspectiva de direitos humanos. Porto Alegre: Núria Fabris, 2009.

. Grupo econômico e sucessão de empresas. In: COSTA, Ângelo Fabiano Farias da; MONTEIRO, Ana Cláudia Rodrigues Bandeira; BELTRAMELLI, Sílvio (Coords.). Reforma trabalhista na visão dos Procuradores do Trabalho. Salvador: Juspodivm, 2018. p. 167-185.

Juruá, 2013.

Inmigración y derechos humanos: um análisis critico del caso brasileño. Curitiba:

LORENZETTI, Ricardo Luís. Fundamentos do direito privado. São Paulo: Revista dos Tribunais, 1998.

LOTTO, Luciana Aparecida. Ação civil pública trabalhista contra o trabalho escravo no Brasil. 2. ed. São Paulo: LTr, 2015.

LUCENA FILHO, Humberto Lima de. A função concorrencial do direito do trabalho. São Paulo: LTr, 2017. 
MADEIRA, Eliane Maria Agati. A Lei das XII Tábuas. [s.d]. Disponível em: $<$ https://s3.amazonaws.com/academia.edu.documents/35425367/ArtigoLeidas 12Tbuas.pdf ?AWSAccessKeyId=AKIAIWOWYYGZ2Y53UL3A\&Expires $=1539784742 \&$ Signature $=$ QHQYch8hvYD4MgG0F6fO2HAQN1A\%3D\&response-contentdisposition=inline $\% 3 \mathrm{~B} \% 20$ filename\%3DA_LEI_DAS_XII_TABUAS.pdf $>$. Acesso em: 10 out. 2018.

MAGANO, Octavio Bueno. Lineamentos de infortunistica. Porto Alegre: José Bushatsky, 1976.

MAIS de 800 trabalhadores são resgatados em condições análogas à escravidão. Governo do Brasil. Portal de Cidadania e Justiça, 2016. Disponível em: $<$ http://www.brasil.gov.br/cidadania-e-justica/2017/04/mais-de-800-trabalhadores-saoresgatados-em-condicoes-analogas-a-escravidao>. Acesso em 20 mar. 2018.

MANÃS, Christian Marcello. A externalização da atividade produtiva: o impacto do teletrabalho na nova ordem socioeconômica. Revista da Faculdade de Direito da Universidade Federal do Paraná - UFPR, Curitiba, v. 39, p. 125-139, 2003. Disponível em: <https://revistas.ufpr.br/direito/article/view/1750/1447>.

MANUS, Pedro Paulo Teixeira. Subordinação estrutural e cadeia produtiva: é acertada esta orientação, em face do conceito de empregado e empregador, da CLT? Magister de Direito do Trabalho, v. 12, n. 70, p. 5-15, jan./fev. 2016.

MARCELINO, Paula. Afinal, o que é terceirização? Em busca de ferramentas de análise e de ação política. PEGADA: a revista da geografia do trabalho, v. 8, n. 2, p. 55-71, dez. 2007.

Disponível em: $<$ http://revista.fct.unesp.br/index.php/pegada/article/download/1640/1570>. . A logística da precarização. São Paulo: Expressão Popular, 2014.

MARES, Radu. Responsability to respect: why the core company should act when affiliates infringe human rights. In: THE UN Guiding Principles on Business and Human Rights - Foundations and Implementation. Leiden; Boston: Martinus Nijhoff Publishers, 2012. p. 169-192. SSRN - Social Science Research Network. Disponível em: $<$ https://papers.ssrn.com/sol3/papers.cfm?abstract_id=2389325>. Acesso em: 11 set. 2018.

MARIN, Marilu Favarin. Trabalho escravo, trabalho livre. 2. ed. São Paulo: FTD, 1999.

MARISA. Sustentabilidade. Disponível em: $<$ https://ri.marisa.com.br/show.aspx?idCanal=/Umex7JusJkI5kYQBhqfZg==>. Acesso em: 08 maio 2018.

MARQUES, Claudia Lima. Contratos no Código de Defesa do Consumidor. 4. ed. rev. atual e ampl. São Paulo: Revista dos Tribunais, 2002.

MARTINELI, Samanta Elisa. As costureiras do MEI: uma análise do trabalho subcontratado das facções do polo regional de confeccções de Maringá-PR. 2017. Dissertação (Mestrado) - Programa de Pós-Graduação em Ciências Sociologia, Universidade Federal do Paraná, Curitiba, 2017. 
MARTINS, Andrea Cristina. A inserção no mundo do trabalho e a proteção jurídica do microempreendedor individual: um estudo no município de Curitiba/PR. 2017. Tese (Doutorado em Ciências Sociais Aplicadas) - Programa de Pós-Graduação em Ciências Sociais Aplicadas, Universidade Estadual de Ponta Grossa, Ponta Grossa, 2017.

MARTINS, José de Souza. O cativeiro da terra. 9. ed. rev. e ampl. São Paulo: Contexto, 2010.

MARTINS, Raphael Manhães. Análise paradigmática do direito das obrigações: boa-fé, deveres laterais e violações positivas do contrato. Revista da EMERJ, Rio de Janeiro, v. 11, n. 44, p. 214-239, 2008.

MARX, Karl. O capital. Trad. R. Enderle. São Paulo: Boitempo, 2013. v. 1.

Grundisse: manuscritos econômicos de 1857-1858: esboços da crítica da economia política. Tradução. Mario Duayer, Nélio Schneider. São Paulo: Boitempo; Rio de Janeiro: Ed. UFRJ, 2011.

MATTOSO, Katia M. de Queiroz. Ser escravo Brasil: séculos XVI-XIX. Trad. S. Furhmann. Petrópolis: Vozes, 2016.

MAXIMILIANO, Carlos. Hermenêutica e aplicação do direito. 8. ed. Rio de Janeiro: Freitas Bastos, 1965.

MBEMBE, Achille. A era do humanismo está terminando. Pensar Contemporâneo, Instituto Humanista Unisinos, 13 maio 2017. Disponível em: $<$ https://www.pensarcontemporaneo.com/humanismo-mbembe/>. Acesso em: 03 nov. 2018.

MEDEIROS NETO, Xisto Tiago de. Lei da reforma trabalhista: a inconstitucionalidade da tarifação dos valores da reparação do dano extrapatrimonial e da determinação de exclusividade da reparação dos dispositivos do novo Título II-A da CLT. In: COSTA, Ângelo Fabiano Farias da; MONTEIRO, Ana Cláudia Rodrigues Bandeira; BELTRAMELLI, Sílvio (Coords.). Reforma trabalhista na visão dos Procuradores do Trabalho. Salvador: Juspodivm, 2018. p. 309-324.

MEILLASSOUX, Claude. Antropologia da escravidão: o ventre de ferro e dinheiro. Tradução Lucy Magalhães Rio de Janeiro: Jorge Zahar, 1995.

MELHADO, Reginaldo. Poder e sujeição: os fundamentos da relação de poder entre capital e trabalho e conceito de subordinação. São Paulo: LTr, 2003.

MELLO, Jean. Lista suja e perfil dos trabalhadores escravizados. SINAIT- Sindicato Nacional dos Auditores Fiscais do Trabalho, Notícias, 17 jan. 2012. Disponível em: $<$ https://www.sinait.org.br/site/noticia-view/?id=4751/lista-suja-e-perfil-dos-trabalhadoresescravizados $>$. 
MELO, Edelamare. O dano extrapatrimonial coletivo ou difuso e a Lei 13.467/017. In: COSTA, Ângelo Fabiano Farias da; MONTEIRO, Ana Cláudia Rodrigues Bandeira; BELTRAMELLI NETO, Sílvio (Coords.). Reforma trabalhista na visão dos Procuradores do Trabalho. Salvador: Juspodivm, 2018. p. 351-383.

MELO, Luís Antônio Camargo de. Premissas para um eficaz combate ao trabalho escravo. Revista do Ministério Público do Trabalho, Brasília, v. 13, n. 26, p. 11-33, set. 2003.

; BRASILIANO; Cristina; MORENO; Jonas Ratier; FABRE, Luiz. Uma Análise do Protocolo Adicional e da Recomendação Acessória à Convenção 29 da OIT Sobre Trabalho Forçado ou Obrigatório. Revista Direitos, Trabalho e Política Social, Cuiabá: Universidade Federal do Mato Grosso, Instituto de Ciências Humanas, v.1, n. 1. 2015.

MENDES, Almara Nogueira. Nova forma de escravidão urbana: trabalho de imigrantes. Revista do Ministério Público do Trabalho, Brasília, v. 13, n. 26, p. 67-70, set. 2003.

MENDES, Marcus Menezes Barberino; CHAVES JR.; José Eduardo de Resende. Subordinação estrutural-reticular: uma perspectiva sobre a segurança jurídica. Revista do Tribunal Regional do Trabalho $3^{a}$ Região, Belo Horizonte, v. 46, n. 76 p. 197-218, jul./dez. 2007. Disponível em: $<$ http://as1.trt3.jus.br/bdtrt3/bitstream/handle/11103/27351/Marcus_Jose.pdf?sequence $=1 \&$ isAllowed $=y>$. Acesso em: 10 ago. 2018.

MERCANTE, Carolina Vieira. A terceirização na indústria de confecções e a reincidência do trabalho análogo ao escravo. GT8 (Grupo de Trabalho) Formas de trabalho degradante. In: ENCONTRO NACIONAL DA ABET, 16., Campinas-SP, 2015. Disponível em: $<$ http://abet2017.com.br/wp-content/uploads/2015/09/CAROLINA-VIEIRAMERCANTE.pdf $>$.

MERÇON, Marineis. Imigrantes bolivianos no trabalho escravo contemporâneo: análise do caso Zara a partir das RPGs. In: JORNADA INTERNACIONAL DE POLÍTICAS PÚBLICAS, 6., São Luís-MA, 2013. São Luis: UFMA, 2013. p. 34-44.

MESZÁROS, István. A crise estrutural do capital. Tradutores A. Carvalhaes, K. Peixoto, F. Cornejo, J. Peschanski, L. Pudenzi, P. Castanheira, S. Lessa. São Paulo: Boitempo, $2011 a$.

Para além do capital: rumo a uma teoria da transição. 1. ed. rev. ed. São Paulo: Boitempo, $2011 b$.

MINISTÉRIO divulga balanço do trabalho escravo em 2014. Governo do Brasil. Portal de Cidadania e Justiça, 2015. Disponível em: <http://www.brasil.gov.br/cidadania-ejustica/2015/01/ministerio-divulga-balanco-do-trabalho-escravo-em-2014>. Acesso em: 10 maio 2017.

MINISTÉRIO divulga lista suja do trabalho escravo. Revista Proteção, 20 out. 2017. Disponível em: $<$ http://www.protecao.com.br/noticias/geral/ministerio_divulga_lista_suja_do_trabalho_es cravo/JyyJAcjaAc/12350>. Acesso em 29 out. 2017. 
MIRAGLIA, Lívia Mendes Moreira. Trabalho escravo contemporâneo: conceituação à luz do princípio da dignidade da pessoa humana. 2. ed. São Paulo: LTr, 2015.

MONTOYA MELGAR, Alfredo. Derecho del trabajo. 20. ed. Madrid: Tecnos, 1999.

MORAES, Evaristo de. Apontamentos de direito operário. 2. ed. comemorativa do Centenário do nascimento do autor acompanhada de introdução feita por Evaristo de Moraes Filho. São Paulo: LTr, 1971.

MORAES, Maria Celina Bodin de (Coord.). Princípios do direito civil contemporâneo. Rio de Janeiro: Renovar, 2006.

MORAES FILHO, Evaristo de. Introdução ao direito do trabalho. 8. ed. rev. atual. e ampl. São Paulo: LTr, 2000.

1. . Tratado elementar de direito do trabalho. Rio de Janeiro: Freitas Bastos, 1956. v.

MORGAN, Andrew (Dir.). The true cost. Produção: Michael Ross. Drama/Documentário, 1h 32m, 2015. [Filme Cinematográfico].

MORICE, Alain. O imigrado e o ilegal: de volta às atividades informais dos estrangeiros. In: PERALVA, Angelina; TELLES, Vera da Silva (Orgs.). Ilegalismos na globalização: trabalho, migrações, mercados Rio de Janeiro: Ed. UFRJ, 2015. p. 136-155.

MORO, Rita de Cássia Lopes. Responsabilidade social na cadeia de fornecedores do varejo de vestuário de moda: estudo de múltiplos casos. 2016. Dissertação (Mestrado em Têxtil e Moda) - Escola de Artes, Ciências e Humanidades, Universidade de São Paulo, São Paulo, 2016.

MOURA, Denise Aparecida Soares. O abastecimento: problema econômico ou político? In: MOURA, Denise Aparecida Soares; CARVALHO, M.; LOPES, Maria-Aparecida. Consumo e abastecimento na história. São Paulo: Alameda, 2011. p. 221-244.

MPF - MINISTÉRIO PÚBLICO FEDERAL. Procuradoria Geral dos Direitos do Cidadão. Nota Técnica $\mathrm{n}^{0}$ 7/2018. A Proteção e Reparação de Direitos Humanos em Relação a Atividades Empresariais. Disponível em: <http://pfdc.pgr.mpf.mp.br/temas-deatuacao/notas-tecnicas/nota-tecnica-pfdc-7-2018>. Acesso em: 05 set. 2018.

MPF: lista suja do trabalho escravo é legítima e se baseia no princípio da transparência. Ministério Público Federal - MPF Notícias, 03 jul. 2018. Disponível em: $<$ http://www.mpf.mp.br/pgr/noticias-pgr/mpf-lista-suja-do-trabalho-escravo-e-legitima-ese-baseia-no-principio-da-transparencia>. Acesso em: 05 jul. 2018.

MPT - MINISTÉRIO PÚBLICO DO TRABALHO. Ação Civil Pública. Inquérito Civil Público $\mathrm{n}^{\mathrm{o}}$ 003933.2013.02.000/5. São Paulo: Procuradoria Regional do Trabalho da $2^{\mathrm{a}}$ Região (SP), 2014. 
MPT - MINISTÉRIO PÚBLICO DO TRABALHO. Coordenadoria Nacional de Erradicação do Trabalho Escravo - CONAETE. Portaria 231 de 12/09/2002. Orientação. Disponível em: <https://portal.mpt.mp.br/wps/wcm/connect/portal_mpt/e346715f-588548a0-af9c-3800148803ba/Orienta\%C3\%A7\%C3\%B5es+-

+ Conaete.pdf?MOD=AJPERES $>$. Acesso em: 16 mar. 2018.

. Inquérito Civil $n^{o}$ 717.2011.02.000. Pernambuco: Procuradoria Regional do Trabalho da $6^{\text {a Região, } 2011 .}$

. Marisa. Inquérito Civil no 788.2006.02.000. São Paulo: Procuradoria Regional do Trabalho da $2^{\text {a }}$ Região, 2006.

Paulo.

MPT x ZARA (2017). TAC aditivo $n^{o}$ 21.2017. IC $n^{o}$ 000393.2011.02.002. São

MPT-C\&A. [s.d.]. Inquérito Civil no 2371.2006.02.000/0-134.

. MPT-RCHLO. [s.d.]. Inquérito Civil $n^{\circ}$ 809.2006.02.000/4-111. São Paulo: Procuradoria Regional do Trabalho da $2^{\mathrm{a}}$ Região, 2006.

- Observatório Digital do Trabalho Escravo no Brasil. [Dados do trabalho escravo]. 2017. Disponível em: <https://observatorioescravo.mpt.mp.br/>. Acesso em 05 ago. 2018.

. Procuradoria Regional do Trabalho no Estado de São Paulo- PRT 2a Região. 20 de abril de 2015. Cadeia de Fornecimento Processo de Industrialização das Peças do Vestuário Zara Brasil Ltda. Termo de Compromisso de Ajustamento de Conduta Inquérito Civil no 000393.2011.02.002/2.

. [s.d.]. Zara x MPT. Inquérito Civil no 393.2011.02.002.

MTE divulga estatísticas do trabalho escravo. Revista Proteção. Fonte: EBC. 28. Out. 2017.

Disponível

em:

http://www.protecao.com.br/noticias/geral/ministerio_divulga_lista_suja_do_trabalho_escr avo/JyyJAcjaAc/12350. Acesso em 29 out. 2017.b.

NAÇÕES UNIDAS. Convenção sobre os Direitos da Criança. Adotada em Assembleia Geral das Nações Unidas em 20 de novembro de 1989. Unicef - Brasil. Disponível em: $<\mathrm{https}$ ://www.unicef.org/brazil/pt/resources_10120.html>. Acesso em: 15 nov. 2018.

NASCIMENTO, Sônia Aparecida Costa Mascaro. A questão do trabalho escravo. Synthesis: direito do trabalho material e processual, São Paulo, n.42, p.18-21, 2006.

NASSER, Salem Hikmat. Fontes do direito internacional: um estudo sobre a soft law. 2. ed. São Paulo: Atlas, 2006.

NEGRÃO, Theotônio; GOUVÊA, José Roberto Ferreira; BONDIOLINI, Luís Guilherme Aidar; FONSECA, João Francisco Naves da. Código Civil e Legislação Civil em vigor. 34. ed. São Paulo: Saraiva, 2016. 
NEGREIROS, Teresa. Teoria do contrato: novos paradigmas. Rio de Janeiro: Renovar, 2002.

NICOLI, Pedro Augusto Gravatá. A condição jurídica do trabalhador imigrante no direito brasileiro. São Paulo: LTr, 2011.

NOGUEIRA, Christiane V.; FABRE, Luiz Carlos M.; KALIL, Renan B.; CAVALCANTI, Tiago M. Recentes avanços legislativos no combate à escravidão. Revista de Direito do Trabalho, São Paulo, v. 40, n. 158, p. 11-28, jul./ago. 2014.a.

; NOVAES, Marina; BIGNAMI, Renato. Tráfico de pessoas e trabalho escravo: além da interposição de conceitos. In: NOGUEIRA, Christiane V.; NOVAES, Marina; BIGNAMI, Renato (Orgs.). Tráfico de pessoas. 1. ed. São Paulo: Paulinas, 2014. b.

NOGUEIRA, L.; IKEAZI, R. A constituição de cooperativas no Nordeste brasileiro. In: DIEESE/CESIT (Orgs.). Emprego e desenvolvimento tecnológico: artigos dos pesquisadores. São Paulo: DIEESE; Campinas: CESIT, 1999. p. 439-447.

NOLAN, Justine. The corporate responsability to respect rights: soft law or not law? (October 4, 2013). Human rights obligations of business: beyond the corporate responsability to respect? S Deva and D Bilchitz (eds.). Cambridge University Press, Nov. 2013. SSRN - Social Science Research Network. Disponível em: $<$ https://papers.ssrn.com/sol3/papers.cfm?abstract_id=2338356>. Acesso em: 10 set. 2018.

NOVAIS, Fernando. Portugal e Brasil na crise do sistema colonial. 8. ed. São Paulo: Hucitec, 1979.

NUCCI, Guilherme de Souza. Código Penal comentado 10. ed. São Paulo: Revista dos Tribunais, 2010.

NUNES, Rizzatto. Curso de direito do consumidor. 8. ed. rev. e atual. São Paulo: Saraiva, 2013.

OIT - ORGANISATION INTERNATIONALE DU TRAVAIL. P029 - Protocole de 2014 relatif à la Convention sur le Travail Forcé, 1930 (11 juin 2014) / Protocole de 2014 relatif à la convention sur le travail forcé (Entrée en vigueur: 09 nov. 2016). Disponível em: $<$ https://www.ilo.org/dyn/normlex/fr/f?p=1000:12100:0::NO::P12100_INSTRUMENT_ID ,P12100_LANG_CODE:3174672,es:NO>. Acesso em 10 nov. 2016.

OIT - ORGANIZAÇÃO INTERNACIONAL DO TRABALHO. C081 - Inspeção do Trabalho na Indústria e no Comércio. Aprovada na $30^{\mathrm{a}}$ reunião da Conferência Internacional do Trabalho (Genebra - 1947), entrou em vigor no plano internacional em 7.4.50. Disponível em: <https://www.ilo.org/brasilia/convencoes/WCMS_235131/lang-pt/index.htm>. Acesso em 05 dez. 2018. 
OIT - ORGANIZAÇÃO INTERNACIONAL DO TRABALHO. Conferência Internacional do Trabalho. $O$ custo da coerção: Relatório Global no seguimento da Declaração da OIT sobre os Direitos e Princípios Fundamentais do Trabalho. Conferência Internacional do Trabalho - 98 ${ }^{\mathrm{a}}$ Sessão 2009. Genebra: OIT, 2009. Disponível em: $<$ https://www.ilo.org/wcmsp5/groups/public/---americas/---ro-lima/---ilo-

brasilia/documents/publication/wcms_227513.pdf $>$.

- Conferência Internacional do Trabalho. Trabalho digno nas cadeias de abastecimento mundiais. Relatório IV. Conferência Internacional do Trabalho, 105. ${ }^{\mathrm{a}}$ Sessão, 2016. Genebra, 2016.

. Declaração Tripartida de Princípios sobre as Empresas Multinacionais e Política Social. In: BUREAU Internacional do Trabalho. 5. ed. Genebra-Suíça: OIT, nov. 1977. Disponível em: $\quad<$ https://www.ilo.org/wcmsp5/groups/public/---ed_emp/--emp_ent/documents/publication/wcms_579899.pdf>.Acesso em: 04 dez. 2018.

. Relatório Global do Seguimento da Declaração da OIT relativa a Princípios e Direitos Fundamentais no Trabalho. Genebra, 2001.

OIT - ORGANIZACIÓN INTERNACIONAL DEL TRABAJO. C029 - Convenio sobre el trabajo forzoso, 1930 (núm. 29). Disponível em: $<$ http://www.ilo.org/dyn/normlex/es/f?p=NORMLEXPUB:12100:0::NO::P12100_ILO_C ODE:C029>. Acesso em: 10 mar. 2018.

OIT divulga relatório sobre trabalho decente nas cadeias produtivas. Portal da Associação Nacional dos Magistrados do Trabalho, 10 jun. 2016. Disponível em: https://www.anamatra.org.br/imprensa/noticias/22581-oit-divulga-relatorio-sobre-trabalhodecente-nas-cadeias-produtivas $>$. Acesso em: 10 jul 2017.

OIT e Brasil promovem $1^{\circ}$ seminário internacional sobre cadeias produtivas globais e trabalho decente. Notícias OIT Brasília. Disponível em: $<$ http://www.ilo.org/brasilia/noticias/WCMS_561127/lang--pt/index.htm>. Acesso em: 12 out. 2018.

OLIVEIRA, Christiana D'Arc Damasceno. (O) direito do trabalho contemporâneo: efetividade dos direitos fundamentais e dignidade da pessoa humana no mundo do trabalho. São Paulo: LTr, 2010.

OLIVEIRA, João Maria de. Empreendedor individual: ampliação da base formal ou substituição do emprego? Radar: tecnologia, produção e comércio exterior, 25 abr. 2013. p. 33-44. Disponível em: $<$ http://www.ipea.gov.br/portal/images/stories/PDFs/radar/130507_radar25_cap3.pdf $>$.

OLIVEIRA, Marco A. Terceirização: estruturas e processos em xeque nas empresas. São Paulo: Nobel, 1994.

OLIVEIRA, Sebastião Geraldo de. Proteção jurídica à saúde do trabalhador. 6. ed. rev. atual. São Paulo: LTr, 2011. 
OMARTIAN, Stormie. A Bíblia da mulher que ora NVI. Trad. N. Siqueira. São Paulo: Mundo Cristão, 2009.

OEA - ORGANIZAÇÃO DOS ESTADOS AMERICANOS. Carta da Organização dos Estados Americanos. 30 de abril de 1948. Disponível em: $<$ http://www.oas.org/dil/port/tratados_A-

41_Carta_da_Organiza $\% \mathrm{C} 3 \% \mathrm{~A} 7 \% \mathrm{C} 3 \% \mathrm{~A} 3 \mathrm{o} \_$dos_Estados_Americanos.htm $>$. Acesso em: 04 out. 2018.

. Comissão Interamericana de Direitos Humanos - CIDH. Relatório $n^{\circ}$ 95/03. Caso 11.289. Solução Amistosa. José Pereira. Brasil, 24 de outubro de 2003. Disponível em: $<$ https://cidh.oas.org/annualrep/2003port/Brasil.11289.htm>. Acesso em 10 jan. 2017.

ONU - ORGANIZAÇÃO DAS NAÇÕES UNIDAS. Conferência das Nações Unidas sobre Meio Ambiente e Desenvolvimento. Declaração do Rio sobre Meio Ambiente e Desenvolvimento, $1992 . \quad$ Disponível em: $<$ http://www.mpf.mp.br/sc/municipios/itajai/gerco/volume-v>. Acesso em: 10 ago. 2018.

Declaração
$\mathrm{https}: / /$ nacoesunidas.org/acao/meio-ambiente/. Acesso em 10.dez.2018.

ONU aponta concentração do poder econômico nas mãos de poucas empresas internacionais. $O N U B R, 26$ set. 2018. Disponível em: <https://nacoesunidas.org/onuaponta-concentracao-do-poder-economico-nas-maos-de-poucas-empresas-internacionais $>$. Acesso em: 01 out. 2018.

OTTO, Hyago de Souza. Reforma trabalhista: o preço dos direitos sociais. Jus Brasil, 2017. Disponível em: <https://hyagootto.jusbrasil.com.br/artigos/437947708/reformatrabalhista-o-preco-dos-direitos-sociais $>$. Acesso em: 31 maio 2018.

PALO NETO, Vito. Conceito jurídico e combate ao trabalho escravo contemporâneo. São Paulo: LTr, 2008.

PARREIRAS, Mateus; RIBEIRO, Luiz; CASTRO, Grasielle. Trabalho escravo no Brasil agora é terceirizado. Jornal Estado de Minas, 14 de Maio de 2013. Disponível em: $<$ https://www.em.com.br/app/noticia/economia/2013/05/14/internas_economia,386873/tra balho-escravo-no-brasil-agora-e-terceirizado.shtml>. Acesso em: 29 set. 2018.

PELUSO, Cesar (Coord.). Código Civil comentado. Barueri-SP: Manole, 2010.

PEREIRA, Caio Mário da Silva. Responsabilidade civil. 9. rev. ed. Rio de Janeiro: Forense, 2002.

PEREIRA, Cícero Rufino. Efetividade dos direitos humanos trabalhistas: o Ministério Público do Trabalho e o tráfico de pessoas. São Paulo: LTr, 2007.

PERES LUÑO, Antonio Enrique. Derechos humanos, Estado de derecho y Constitución. 5. ed. Madrid: Tecnos, 1995. 
PERFIL do Setor. Dados gerais do setor referentes a 2017 (atualizados em outubro de 2018). Disponível em: <http://www.abit.org.br/cont/perfil-do-setor>. Acesso em: 06 jun. 2017.

PERLINGIERI, Pietro. Perfis do direito civil: introdução ao direito civil constitucional. Trad. M. C. Cicco. Rio de Janeiro: Renovar, 1997.

PERNAMBUCANAS é condenada por trabalho análogo à escravidão. Tribunal Regional do Trabalho da $2^{a}$ Região, 17 ago. 2017. Disponível em: <http://www.trtsp.jus.br/indicede-noticias-noticias-juridicas/21241-pernambucanas-e-condenada-por-trabalho-analogo-aescravidao. Acesso em: 18 ago. 2017.

PESSOA, André Magalhães. a nova disciplina do dano extrapatrimonial na CLT: considerações sobre a responsabilidade civil do empregador diante das mudanças inseridas pela Lei n. 13.467, de 2017. In: COSTA, Ângelo Fabiano Farias da; MONTEIRO, Ana Cláudia Rodrigues Bandeira; BELTRAMELLI, Silvio (Coords.). Reforma trabalhista na visão dos Procuradores do Trabalho. Salvador: Juspodivm, 2018. p. 325-350.

PHILLIPS, Nicola. Mirando nas redes globais de produção e acertando no trabalho forçado. In: FIGUEIRA, Ricardo Rezende; PRADO, Adonia Antunes; SANT'ANA JÚNIOR, Horácio Antunes de (Orgs.). Trabalho escravo contemporâneo: um debate transdisciplinar. Rio de Janeiro: Mauad X, 2011. p. 157-178.

PINSKY, Jaime. A escravidão no Brasil. 21. ed. São Paulo: Contexto, 2015.

PLÁ RODRIGUEZ, Américo. Principios de direito do trabalho. São Paulo: LTr, 2015.

POCHMANN, Marcio. O emprego e o desenvolvimento da nação. São Paulo: Boitempo, 2008.

. O mito da grande classe média. São Paulo: Boitempo, 2014.

PORTER, Michael E. Competitive advantage: creating and sustaining superior performance. New Yorl and London: The Free Press, 1985.

. The competitive advantage of Nations. New York: The Free Press, 1990.

PORTO, Lorena Vasconcelos. A subordinação no contrato do trabalho: uma releitura necessária. São Paulo: LTr, 2009.

PRADO JR., Caio. História econômica do Brasil. São Paulo: Brasiliense, 2012.

PROCHNIK, Victor. Cadeias produtivas e complexos industriais. In: HANSENCLEVER, Lia; KUPFER, David (Orgs.). Economia industrial: fundamentos teóricos e práticas no Brasil. Rio de Janeiro: Campus, 2002. Seção do capítulo Firma, Indústria E Mercados.

PROCURADOR-GERAL do Trabalho critica fim de ministério: 'consequências graves'. [erntrevista]. Jornal da CBN, 08 nov. 2018. Disponível em: $<$ https://cbn.globoradio.globo.com/media/audio/225833/procurador-geral-do-trabalhocritica-fim-de-minist.htm>. Acesso 10.nov.2018. 
PROST, Antoine. Fronteiras e espaços do privado. In: PROST, Antoine; VINCENT, Gérard (Orgs.). História da vida privada: da Primeira Guerra aos nossos dias. Tradução Denise Bottmann. 1. reimpr. São Paulo: Ed. Companhia das Letras, 1987.

PYL, Bianca. De La Paz para São Paulo, a história de exploração de uma vítima do tráfico de pessoas. Repórter Brasil, 27 jul. 2012. Disponível em: $<$ http://reporterbrasil.org.br/2012/07/de-la-paz-para-sao-paulo-a-historia-de-exploracao-deuma-vitima-do-trafico-de-pessoas/>. Acesso em 10 mar. 2018.

; HASHIZUME, Maurício. Roupas da Zara são fabricadas com mão de obra escrava. Repórter Brasil, 16 ago. 2011. Disponível em: $<$ https://reporterbrasil.org.br/2011/08/roupas-da-zara-sao-fabricadas-com-mao-de-obraescrava/>. Acesso em: 02 jun. 2016.

QUEIROGA, Antônio Elias de. Responsabilidade civil e o novo Código Civil. Rio de Janeiro: Renovar, 2003.

QUIRK, Joel. The anti-slavery project: linking tha historical and contemporany. Human Rights Quaterly, v. 28, n. 3, p. 565-598 Aug. 2006. Disponível em: $<$ http://www.artsrn.ualberta.ca/amcdouga/Hist494/resources/quirk\%20antislavery\%20project.pdf $>$.

RAMOS, André de Carvalho. Teoria geral dos direitos humanos na ordem internacional. 5. ed. São Paulo: Saraiva, 2015.

RAPASSI, Rinaldo Guedes. Subordinação estrutural, terceirização e responsabilidade no Direito do Trabalho. Revista do Tribunal Regional do Trabalho da $10^{a}$ Região, v. 15/18, p. 105-109, 2008. Acesso em: 10 nov. 2018. Disponível em: $<$ https://juslaboris.tst.jus.br/bitstream/handle/20.500.12178/75795/2008_rapassi_rinaldo_s ubordinacao_estrutural.pdf? sequence=1>. Acesso em: 10 nov. 2018.

RECH, Sandra Regina. Cadeia produtiva da moda: um modelo conceitual de análise da competitividade no elo de confecção. 2006. Tese (Doutorado) - Programa de PósGraduação em Engenharia de Produção, Universidade Federal de Santa Catarina, Florianópolis-SC, 2006.

. Estrutura da cadeia produtiva da moda. ModaPalavra E-periódico, v. 1, n. 1, p. 720, jan./jul. 2008. Disponível em: $<$ http://www.revistas.udesc.br/index.php/modapalavra/article/view/7565/5068>.

REICH, Robert B. The Work of Nations: Preparing Ourselves for 21st Century Capitalism. Nova York: Random House, 1991.

REPÓRTER BRASIL. Escravo, nem pensar! 2004. Acesso em 10 maio 2017. Disponível em: $<$ http://escravonempensar.org.br $>$. 
REPÓRTER BRASIL; SOMO. Da responsabilização moral à responsabilização jurídica? As condições de escravidão moderna na cadeia global de suprimentos da indústria do vestuário e a necessidade de fortalecer os marcos regulatórios:o caso da Inditex-Zara no Brasil. Repórter Brasil; SOMO, maio 2015. Disponível em: $<$ https://reporterbrasil.org.br/wp-content/uploads/2015/05/Reporter-Brasil-web-P.pdf $>$.

RESCIGNO, Pietro. Manuale Del Diritto Privato Italiano. ( $11^{\mathrm{a}}$ ed.). Napoli: Eugenio Jovene, 1994.

ROCHA, Afonso de Paula Pinheiro. Responsabilidade civil trabalhista contemporânea: delineamentos atuais e diretivas para o manejo da responsabilidade civil contemporânea no âmbito trabalhista. 2016. Tese (Doutorado em Direito Constitucional) - Centro de Ciências Jurídicas, Universidade de Fortaleza, 2016.

ROCHA, Graziela do Ó; GÓIS, João Bôsco Hora. Da lista suja às ações reparadoras: um estudo sobre o processo de responsabilização de uma siderúrgica pela existência de trabalho escravo em sua cadeia produtiva. In: FIGUEIRA, Ricardo Rezende; PRADO, Adonia Antunes; SANT'ANA JÚNIOR, Horácio Antunes de (Orgs.). Trabalho escravo contemporâneo: um debate transdisciplinar. Rio de Janeiro: Mauad X, 2011. p. 253-268.

ROCHA, O. A subordinação e sua insuficiência para integral visualização do contrato individual de trabalho objetivamente. Revista do Tribunal Superior do Trabalho, n. 51, 1978. vol. 88 .

RODRIGUES, Silvio. Direito civil: responsabilidade civil. São Paulo: Saraiva, 2002.

RODRIGUES JR., Edson Beas. A função empresarial do direito do trabalho e a repressão local à concorrência predatória internacional viabilizada pelo dumping social. Revista de Direito do Trabalho. São Paulo: Revista dos Tribunais, v. 40, n. 160, nov./dez. 2014. p. 49-116.

ROLIM, L. A. Instituições de direito romano. São Paulo: Revista dos Tribunais, 2000.

ROLLI, Claudia; FERNANDES, Fátima. Rede Marisa é autuada por trabalho irregular. Folha de São Paulo, São Paulo, 18 mar. 2010. Disponível em: $<$ https://www1.folha.uol.com.br/fsp/dinheiro/fi1803201021.htm $>$. Acesso em: 18. jun. 2017.

$\overline{09} ;-\begin{array}{ccc}\text { Varejo faz acordo sobre bolivianos ilegais. Folha de S. Paulo, São Paulo, } \\ \text { dez. }\end{array}$ $<$ https://www1.folha.uol.com.br/fsp/dinheiro/fi0912200716.htm>. Acesso em: 08 maio 2018.

ROMITA, Arion Sayão. A subordinação no contrato de trabalho. Rio de Janeiro: Forense, 1979. 
ROSENBAUM, Jorge. La progresiva subsunción de la figura del "empleador complejo" en el curso evolutivo del ordenamiento jurídico nacional. $R C J, 19$ jun. 2012. Disponível em: $<$ http://www.rcj.com.uy/web/26/Art\%C3\%ADculo/La-progresiva-subsunci\%C3\%B3n-dela-figura-del-\%E2\%80\%9Cempleador-complejo\%E2\%80\%9D-en-el-curso-evolutivo-delordenamiento-jur\%C3\%ADdico-nacional.html>. Acesso em: 18 nov. 2018.

RUGGIE, John Gerard. Conselho de Direitos Humanos aprova princípios orientadores para empresas. $O N U B R, 17$ jun. 2011. Disponível em: $<$ https://nacoesunidas.org/conselho-dedireitos-humanos-aprova-principios-orientadores-para-empresas>. Acesso em: 10 nov. 2018.

. Just business: multinational corporations and human rights. NYC-London: Norton \& Company, 2013.

SAKAMOTO, Leonardo. Dados de resgates mostram relação entre trabalho escravo e terceirização. Portal Uol, 30 mar. 2017. Disponível em; $<$ https://blogdosakamoto.blogosfera.uol.com.br/2017/03/30/dados-de-resgates-mostramrelacao-entre-terceirizacao-e-trabalho-escravo>. Acesso em: 29 set. 2018.

(Coord. do estudo). Trabalho escravo no Brasil do século XXI. Brasil: OIT, 2006.

. LOCATELLI, Piero. M. Officer afirma e comprova nunca ter praticado trabalho escravo e irá recorrer da injusta decisão trabalhista. Repórter Brasil. 08 nov. 2017. Disponível em: $\quad<$ https://reporterbrasil.org.br/wp-content/uploads/2017/11/INFOMOFFICER.pdf>. Acesso em: 10 mar. 2018.

. Tribunal condena M. Officer por escravidão. Reporter Brasil, 08 nov. 2017. Disponível em: <https://reporterbrasil.org.br/2017/11/tribunal-condena-m-officerpor-escravidao/>. Acesso em: 10 dez. 2017.

SAMPAIO, Francisco José Marques. Evolução da responsabilidade civil e reparação dos danos ambientais. Rio de Janeiro: Renovar, 2003.

SANCHEZ VAZQUEZ, Adolfo. Ética. Rio de Janeiro : Civilizacao Brasileira, 1993.

SANDEL, Michael J. Justiça: o que é fazer a coisa certa. 16. ed. Trads. H. Matias, M. Máximo, Michael J. Rio de Janeiro: Civilização Brasileira, 2014.

SANTOS, Anselmo Luís dos; GIMENEZ, Denis Maracci. Desenvolvimento, competitividade e a reforma trabalhista. In: GIMENEZ, Denis Maracci; KREIN; José Dari; SANTOS, Anselmo Luís do (Orgs.). Dimensões críticas da reforma trabalhista no Brasil. Campinas: Curt Nimuendajú, 2018. p. 27-68.

SANTOS, Boaventura de Sousa. Os processos de globalização. In: SANTOS, Boaventura de Sousa (Org.). A globalização e as ciências sociais. São Paulo: Cortez, 2001. p. 24-94.

SANTOS, Marco Antonio dos. As alterações do art. $8^{\circ}$ da CLT com o advento da Lei $n$. 13.467/2017. In: SOUZA JÚNIOR, Antonio Umberto de et al. (Coords.). Reforma trabalhista: análises e comentários sobre a Lei n. 13.467/2017. São Paulo: LTr, 2018. p. 29-36. 
SANTOS, Milton. Por uma globalização mais humana. Folha de S. Paulo. São Paulo, 30 nov. 1995. Disponível em: <www.revistaprosaversoearte.com/por-uma-globalizacao-maishumana-texto-geografo-milton-santos>. Acesso em: 21 set. 2018.

SANTOS, Rodrigo Salles Pereira dos. Redes de Produção Globais (RPGs): contribuições conceituais para a pesquisa em ciências sociais. Revista Pós Ciências Sociais, Universidade Federal do Maranhão, Programa de Pós-graduação em Ciências Sociais, v. 8, n. 15, p. 127-142, 232, jan./jun. 2011.

SANTOS, Ronaldo Lima dos. A escravidão por dívidas nas relações de trabalho do Brasil contemporâneo. Revista do Ministério Público do Trabalho, Brasília, v. 13, n. 26, p. 47-66, set. 2003.

Evolução histórico-normativa da tutela jurídica do meio ambiente do trabalho e instrumentos de proteção. In: JARDIM, Philippe Gomes; LIRA, Ronaldo José de (Coords.). Meio ambiente do trabalho equilibrado: homenagem aos dez anos de CODEMAT. São Paulo: LTr, 2013. p. 220-237.

SARLET, Ingo Wolfgang. Dignidade da pessoa humana e direitos fundamentais na Constituição de 1988. 8. ed. rev. atual. e ampl. Porto Alegre: Livr. do Advogado, 2010.

SARMENTO, Daniel. Direitos undamentais e relações privadas. Rio de Janeiro: Lumen Juris, 2004.

SASSO, Nathalia. Movimento global denuncia o trabalho escravo na moda. Humanista: jornalismo e direitos humanos, 14 jun. 2018. Disponível em: $<$ https://www.ufrgs.br/humanista/2018/06/14/movimento-global-denuncia-o-trabalhoescravo-na-moda/>. Acesso em: 29 set. 2018.

SCHIMANSKI, Silvana; ZHANG, Liping. Cadeias globais de valor e os países em desenvolvimento. Boletim de Economia e Política Internacional (BEPI), n. 18, p. 73-92, set./dez. $2014 . \quad$ Disponível em: $<$ http://www20.iadb.org/intal/catalogo/PE/2015/15323.pdf $>$.

SCHWARZ, Rodrigo Garcia. Trabalho escravo: a abolição necessária: uma análise da efetividade e da eficácia das políticas de combate à escravidão contemporânea no Brasil. São Paulo: LTr, 2008.

SEBRAE. Cadeia produtiva têxtil e de confecções: cenários econômicos e estudos setoriais. Recife: Reprocenter, 2008.

SEGATTI, Ana Elisa Alves Brito; NOGUEIRA, Christiane Vieira; NOVAES, Dirce Trevisi Prado; SABINO, João Filipe Moreira Lacerda; FORTES, Mariana Flesch. Trabalho escravo; reflexões sobre a responsabilidade na cadeia produtiva. Revista do Ministério Público do Trabalho em São Paulo, n. 3, p. 13-34, 2015. 
SEGATTI, Ana Elisa Alves Brito; NOVAES, Dirce Trevisi Prado; NOGUEIRA, Christiane Vieira; SABINO, João Filipe Moreira Lacerda; FORTES, Mariana Flesch. Trabaho escravo: reflexões sobre a responsabilidade na cadeia produtiva. In: FIGUEIRA, Ricardo Rezende; PRADO, Adonia Antunes; GALVÃO, Edna Maria (Orgs.). Discussões contemporâneas sobre trabalho escravo: teoria e pesquisa. Rio de Janeiro: Mauad X, 2016.

SENNET, Richard. A corrosão do caráter: consequencias pessoais do trabalho no novo capitalismo. Trad. Marcos Santarrita. 6. ed. Rio de Janeiro: Record, 2002.

SENTO-SÉ, Jairo Lins de Albuquerque. Trabalho escravo no Brasil na atualidade. São Paulo: LTr, 2000.

SEVERO, Fabiana Galera. Trabalho escravo urbano contemporâneo no Brasil: análise dos mecanismos de repressão e prevenção para a efetivação de direitos humanos. 2017. Dissertação (Mestrado) - Programa de Pós-Graduação em Direito da Faculdade de Direito da Universidade de São Paulo, São Paulo, 2017a.

SEVERO, Valdete Souto. A hermenêutica trabalhista e o princípio do direito do trabalho. In: SOUTO MAIOR, Jorge Luiz; SEVERO, Valdete Souto (Coords.). Resistência: aportes teóricos contra o retrocesso trabalhista. São Paulo: Expressão Popular, 2017b. p. 29-46.

; SOUTO MAIOR, Jorge Luiz. Manual da reforma trabalhista: pontos e contrapontos. São Paulo: Sensus, 2017c.

SILVA, Cristiane de Melo Mattos Sabino Gazola. Do escravismo colonial ao trabalho forçado atual: a supressão dos direitos sociais fundamentais. São Paulo: LTr, 2009.

SILVA, Hiago Trindade de Lira. No fio da meada: um estudo acerca da precarização do trabalho na indústria têxtil. Temporalis, Brasília-DF, ano 16, n. 32, p. 375-398, jul./dez. 2016.

SILVA, Homero Batista Mateus da. Comentários à reforma trabalhista: análise da Lei $\mathrm{n}^{\mathrm{o}}$ 13.467/2017 - artigo por artigo. São Paulo: Ed. Revista dos Tribunais, 2017.

SILVA, Laércio Lopes da. A terceirização e a precarização nas relações de trabalho: a atuação do juiz na garantia da efetivação dos direitos fundamentais nas relações assimétricas de poder: uma interpretação crítica ao PL n. 4.330/2004. São Paulo: LTr, 2015.

SILVA, Mércia. C. Fazenda Brasil Verde e as cadeias produtivas. In: MINISTÉRIO DOS DIREITOS HUMANOS - MHD. Comissão Nacional para a Erradicação do Trabalho Escravo - CONATRAE. Trabalho escravo: condenação do Brasil pela Corte Interamericana de Direitos Humanos no Caso Fazenda Brasil Verde. Brasília-DF: CONATRAE, 2017.

SILVA, Naiara de Moraes e. A política pública de emprego e renda $e$ o microempreendedorismo individual: a realidade dos empreendimentos no shopping da cidade em Teresina-PI. 2016. Tese (Doutorado em Políticas Públicas) - Universidade Federal do Piauí, Teresina, 2016. 
SILVA, Silvana Cristina da. Circuito espacial produtivo das confecções e exploração do trabalho na metrópole de São Paulo: os dois circuitos da economia urbana nos bairros do Brás e Bom Retiro (SP). 2012. Tese (Doutorado) Programa de Pós-Graduação em Geografia, Universidade Estadual de Campinas, Campinas, 2012.

SIMON, Fernanda. Fashion Revolution Brazil. Fashion Revolution Brazil. [s.d.]. Disponível em: <https://www.fashionrevolution.org/south-america/brazil/>. Acesso em: 02 dez. 2018.

SINAIT. (s.d.). Trabalho escravo contemporâneo. Sindicato Nacional dos Auditores Fiscais do Trabalho. Disponível em: <https://www.sinait.org.br/site/index/?mobile=true >. Acesso em: 10 jan. 2017.

SOUTO MAIOR, Jorge Luiz. O direito do trabalho como instrumento de justiça social. São Paulo: LTr, 2000.

. História do direito do trabalho no Brasil: curso de direito do trabalho. São Paulo: LTr, 2017. v. $1^{\mathrm{a}}$.

. Terceirização da atividade fim e o fim da terceirização. Blog do Jorge Souto Maior, 18 jun. 2017. Disponível em: $<$ http://www.jorgesoutomaior.com/blog/terceirizacaoda-atividade-fim-e-o-fim-da-terceirizacao $>$. Acesso em: 10 jan. 2018.b

Terceirização: desabafo, desmascaramento e enfrentamento. Blog da Boitempo, 2015. Disponível em: $<$ https://blogdaboitempo.com.br/2015/04/13/terceirizacao-desabafodesmascaramento-e- enfrentamento $>$. Acesso em: 10 jan. 2016.

; SEVERO, Valdete Souto; MOREIRA, Ranúlio Mendes. Dumping social nas relações de trabalho. 2. ed. São Paulo: LTr, 2014.

STEPHENSON, Sherry M. Cadeias globais de valor: a nova realidade do comércio internacional. Bridges Network - Pontes: Informações e análises sobre comércio e desenvolvimento sustentável., v. 11, n. 2, 27 mar. 2015. Genebra, Suiça, ICTSD. Disponível em: <http:/www.ictsd.org/bridges-news/pontes/news/cadeias-globais-de-valora-nova-realidade-do-com\%C3\%A9rcio-internacional>. Acesso em: 13 maio 2017.

STF - SUPREMO TRIBUNAL FEDERAL. ADPF 489. Disponível em: $<$ http://portal.stf.jus.br/processos/detalhe.asp?incidente $=5293382>$. Acesso em: 10 out. 2018.

. Analise do tema 725 da repercussão geral: Terceirização de serviços, RE 958252 (Supremo Tribunal Federal, 29 de agosto de 2018).

Distribuição de medicamentos gratuita pelo Estado, RE 271.286 AgR. Rel. Min. Celso de Mello, j. 12-9-2000, $2^{\mathrm{a}}$ T, P, DJ de 24-11-2000. (STF, 2000). de 2014).

Inconstitucionalidade de fixação de indenização, RE 396.386-SP (STF 13 de 08 
STF - SUPREMO TRIBUNAL FEDERAL. Mensalão, AP nº 470. Rel. Min. Rosa Weber. (STF 2012).

. Prisão civil do depositário infiel, RE 466.343. Rel. Min. Cezar Peluso, voto do min. Gilmar Mendes. (STF-2009).

STOCO, Rui. Responsabilidade civil e sua interpretação jurisprudencial. São Paulo: Revista dos Tribunais, 1997.

. Tratado de responsabilidade civil. São Paulo: Revista dos Tribunais, 2004.

STURGEON, Timothy J. How we define value chain and production network? In: GLOBALIZATION study, MIT IPC Working Paper 00-010. Background Paper Prepared for the Bellagio Value Chains Workshop, Sept. 25 - Oct. 1, 2000. Massachusetts- USA, 2000 .

SUPIOT, Alain. La gouvernance par les nombres. Cours au Collège de France, 20122014. Nantes-FR: Librairie Arthème Fayard en partenariat avec l'Institut d'Études Avancées de Nantes, 2015.

SÜSSEKIND, Arnaldo. Comentários à Consolidação das Leis do Trabalho e à legislação complementar. Rio de Janiero- São Paulo: Freitas Bastos, 1960. v. 1.

; MARANHÃO, Délio; VIANNA, Segadas; TEIXEIRA FILHO, João de Lima. Instituições de direito do trabalho. 22. ed. São Paulo: LTr, 2005. v. 1.

SUTTON, Alison. Trabalho escravo: um elo na cadeia da modernização do Brasil de hoje. Tradução, Siani Maria Campos. São Paulo: Edições Loyola, 1994.

TARTUCE, Flávio. Manual de direito civil. 2. ed. São Paulo: Método, 2012.

; NEVES, Daniel Amorim Assumpção. Manual de direito do consumidor: direito material e processual. São Paulo: Método, 2013.

TEIXEIRA, Bárbara Bittar. Direitos humanos e empresas: a responsabilidade por exploração de trabalhadores em condições análogas à de escravo nas cadeias produtivas da indústria têxtil. 2018. Dissertação (Mestrado) - Direito - Faculdade Getúlio Vargas, São Paulo, 2018.

TEIXEIRA, Bruno Cesar Gonçalves. Os efeitos deletérios da reforma trabalhista na execução judicial. Consultor Jurídico, 02 maio 2017. Disponível em: $<$ https://www.conjur.com.br/2017-mai-02/bruno-teixeira-efeitos-deleterios-reformatrabalhista-execucao-judicial>. Acesso em: 02 nov. 2017.

TEPEDINO, Gustavo. Temas de direito civil. Rio de Janeiro: Renovar, 2008. . Temas de direito civil. Rio de Janeiro: Renovar, 2009. v. 3. 
TEUBNER, Gunther; COLLINS, Hugh; Netowrk as connected contracts. Oxford: Hart. 2011.

THIBAULT ARANDA, Javier. El teletrabajo: análisis jurídico-laboral. Madrid: Consejo Económico y Social, 2001.

TIMÓTEO, Gabrielle Louise Soares. Normativos internacionais e escravidão. In: FIGUEIRA, Ricardo Rezende; PRADO, Adonia Antunes; GALVÃO, Edna Maria (Orgs.). Privação da liberdade ou atentado à dignidade: escravidão contemporânea. Rio de Janeiro: Mauad X, 2013. p. 107-124.

. Os trabalhadores bolivianos em São Paulo: uma abordagem jurídica. 2011. Dissertação (Mestrado em Direito) - Programa de Pós-Graduação em Direito da Faculdade de Direito da Universidade de São Paulo, São Paulo, 2011.

TOMICH, Dale. W. Pelo prisma da escravidão: trabalho, capital e economia mundial. Trad. A. de Paula Danesi. São Paulo: Edusp, 2011.

TORRES, Daniel Betolucci. Vulnerabilidade e exploração: considerações sobre a relação entre o imigrante e o trabalho em condição análoga à de escravo. In: FREITAS JÚNIOR, Antonio Rodrigues; TORRES, Daniel Betolucci; BOUCINHAS FILHO, Jorge Cavalcanti (Orgs.). Migração, trabalho e direitos humanos. São Paulo: LTr, 2017. p. 117-132.

TORRINHA, Francisco. Dicionário latino-português. Porto: Gráficos Reunidos, 1942.

TRF3 - TRIBUNAL REGIONAL FEDERAL DA $3^{\mathrm{a}}$ REGIÃO. Disponível em: $<$ www.trf3.jus.br>. Acesso em: 10 set. 2018.

TRT mantém condenação da Pernambucanas por trabalho escravo. Veja, São Paulo, 18 ago. 2017. Disponível em: $<$ https://veja.abril.com.br/economia/trt-mantem-condenacao-dapernambucanas-por-trabalho-escravo/>. Acesso em: 28 ago. 2017.

TRT1 - TRIBUNAL REGIONAL FEDERAL DA PRIMEIRA REGIÃO. Crime de Trabalho Escravo, 0000866-24.2007.4.01.3904 (TRF - Primeira Região 04 de 09 de 2018). Disponível em: <https://www2.cjf.jus.br/jurisprudencia/trf1/index.xhtml>. Acesso em: 10 set. 2018.

TRT2 - TRIBUNAL REGIONAL DO TRABALHO DA $2^{\mathrm{a}}$ REGIÃO. $3^{\mathrm{a}}$ Vara do Trabalho em São Paulo. Caso Zara. Ação Anulatória, Processo no 000166291.2012.5.02.0003 e 00089052720145020000 - Ação Cautelar ( $3^{\mathrm{a}}$ Vara do Trabalho em São Paulo- $4^{\mathrm{a}}$ Turma do TRT 2a Região 2012).

. 54 ${ }^{\mathrm{a}}$ Vara do Trabalho. ACP M. Officer, 00017795520145020054 e 00030149120135020054. (54 ${ }^{\mathrm{a}}$ Vara do Trabalho- TRT $2^{\mathrm{a}}$ Região, 25 de setembro de 2015).

. 54 ${ }^{\mathrm{a}}$ Vara do Trabalho. Termo de Audiência. Processo n $\mathrm{n}^{\mathrm{o}}$ 000177955.2014.5.02.0054 e 00030149120135020054. Disponível em: $<$ http://www.trtsp.jus.br/NOTICIAS/20161108_sentenca\%20mofficer.pdf $>$. Acesso em: 25 set. 2016. 
TRT2 - TRIBUNAL REGIONAL DO TRABALHO DA 2 $2^{\mathrm{a}}$ REGIÃO. Acompanhamento Processual em $2^{a}$ Instância. Disponível em: $<$ http://aplicacoes8.trtsp.jus.br/sis/index.php/segundaInstancia>. Acesso em: 29 maio 2018.

. Caso M. Officer, ACP 00017795520145020054 e $00030149120135020054-54^{\mathrm{a}}$ Vara do Trabalho de São Paulo. D.J. 25 set. 2015. (4 ${ }^{\mathrm{a}}$ Turma do TRT $2^{\mathrm{a}}$ Região 2015). Disponível em: <www.trt2.jus.br>. Acesso em: 10 maio 2018.

. Caso Pernambucanas, ACP 0000108-81.2012.5.02.0081- $81^{\mathrm{a}}$ Vara do Trabalho de São Paulo (7 $7^{\mathrm{a}}$ Turma TRT $2^{\mathrm{a}}$ Região 2012). Disponível em: <www.trt2.jus.br>. Acesso em: 10 maio 2018.

. Cautelar M. OFFICER, 003014-91.2013.5.02.0054 (54 ${ }^{\text {a }}$ Vara do Trabalho de SP Nov. de 2013). Disponível em: <www.trt2.jus.br>. Acesso em: 10 fev. 2017.

. Disponível em: <www.trt2.jus.br>. Acesso em: 10 maio 2018.

. Justiça do Trabalho - $2^{\mathrm{a}}$ Região. $87^{\mathrm{a}}$ Vara do Trabalho em São Paulo. Termo de Audiência. Proc. $\quad n^{o}$ 0001875-39.2012.5.02.0087. Disponível em: $<$ http://reporterbrasil.org.br/wp-

content/uploads/2013/02/SentencaPrimeiraInstanciaMarisa.pdf $>$. Acesso em: 10 maio 2017.

. Marisa - Ação Anulatória de AI, 0001875-39.2012.5.02.0087 (87 ${ }^{\mathrm{a}}$ Vara do $\overline{\text { Trabalho }}$ - TRT 2a Região-Sp 31 de 01 de 2013). Disponível em: <www.trt2.jus.br>. Acesso em: 25 maio 2018. de 2014).

. Responsabilidade solidária costura, 0013450.2010.5.02.00050. (D.O.U. 20 de set

RR Marisa, RE-0001875-39.2012.5.02.0087 (TRT 2a Região 14 de 08 de 2015). Disponível em: <www.trt2.jus.br>. Acesso em: 12 maio 2018.

TRT-21 - TRIBUNAL REGIONAL DO TRABALHO DA $21^{\mathrm{a}}$ REGIÃO. Caso Guararapes - Grupo Riachuelo, Ação Civil Pública nº 000694-45.2017.5.21.0007 (7 7ara $^{\mathrm{a}}$ do Trabalho - TRT 21 ${ }^{\mathrm{a}}$ Região 2017). Disponível em: $<$ https://pje.trt21.jus.br/consultaprocessual/pages/consultas/DetalhaProcesso.seam?p_num pje $=146275 \& p \_g r a u \_p j e=1 \& p \_s e q=0000694 \& p \_d i g \_c n j=45 \& p \_a n o \_c n j=>$. Acesso em: 05 set. 2018.

TRT3 - TRIBUNAL REGIONAL DO TRABALHO DA $3^{\mathrm{a}}$ REGIÃO - MG. Facção e Responsabilidade da Cadeia Produtiva, Processo n. 0010178-16.2016.5.03.0106 (TRT-3 16 de 06 de 2017).

TSING, Anna. Supply chains and the human condition. Rethinking Marxism: a journal of economics, culture \& society, v. 21, n. 2, p. 148-176, 2009. doi:10.1080/0893569090274308. 
TST - TRIBUNAL SUPERIOR DO TRABALHO. AIRR - 1179-56.2016.5.14.0401, Relator Ministro: Mauricio Godinho Delgado, Data de Julgamento: 17/10/2018, $3^{\text {a }}$ Turma, DEJT 19/10/2018). Disponível em: <http://www.tst.jus.br/consulta-unificada $>$. Acesso em: 05.out. 2018.

Disponível em: <www.tst.jus.br>. Acesso em: 10 jan. 2017.

. E-ED-ED-RR - 2320-40.2012.5.03.0019, Relator Ministro: Augusto César Leite de Carvalho, Data de Julgamento: 14/06/2018, Subseção I Especializada em Dissídios Individuais, DEJT 21/09/2018). Disponível em: <http://www.tst.jus.br/consultaunificada>. Acesso em: 05.out. 2018.

. Facção Autonomia, RR 537-34.2010.5.12.0039 (5 $5^{\mathrm{a}}$ Turma. Rel. Ministro: Emmanoel Pereira. DEJT, 20.11.2012). Disponível em: $<$ https://tst.jusbrasil.com.br/jurisprudencia/168422921/recurso-de-revista-rr1143320135090025/inteiro>. Acesso em: 10 nov. 2018.

. Facção, AIRR - 269-53.2013.5.03.0041 (TST- $7^{\mathrm{a}}$ Turma 23 de 05 de 2014).

. Pesquisa Processual. Disponível em: <http://www.tst.jus.br/web/guest/processosdo-tst>. Acesso em: 19 ago. 2018.

Recurso de Revista: RR 1143320135090025. Disponível em: $\overline{<\mathrm{https}}$ :/tst.jusbrasil.com.br/jurisprudencia/168422921/recurso-de-revista-rr1143320135090025/inteiro-teor-168422942>. Acesso em: 30 maio 2018.

. Requisitos da relação de emprego, RR - 1236-44.2011.5.03.0017 (TST, $3^{\text {a }}$ Turma 18 de 11 de 2016). Disponível em: <http://www.tst.jus.br/consulta-unificada>. Acesso em: 05 mar. 2018.

. Terceirização, RR - 130300-89.2003.5.02.0058 (DOU 04.06.2014). Disponível em www.tst.jus.br>. Acesso em: 15 maio 2017.

TUPIASSU, Alessandra de Cássia Fonseca Tourinho. Trabalho e desenvolvimento cadeias produtivas transnacionais - relações de trabalho e o papel do sindicato. Revista LTr, São Paulo, v. 75, n. 4, p.421-429, abr. 2011.

UNITED KINGDOM-UK. Modern Slavery Act 2015. Disponível em: $<$ http://www.legislation.gov.uk/ukpga/2015/30/section/15/enacted $>$. Acesso em: 04 mar. 2018.

UNITED NATIONS. Disponível em: $<$ https://documents-ddsny.un.org/doc/RESOLUTION/GEN/G11/144/74/PDF/G1114474.pdf?OpenElement>. Acesso em: 15 out. 2017.

Fact Sheet No. 14, Contemporary Forms of Slavery. 1991. Disponível em: $\overline{<\mathrm{https} / / / w w w . o h c h r . o r g / D o c u m e n t s / P u b l i c a t i o n s / F a c t S h e e t 14 e n . p d f ~}>$. Acesso em: 10 maio. 2018. 
UNITED NATIONS. Guiding Principles on Business and Human Rights: Implementing the United Nations 'Protect, Respect and Remedy' Framework. New York; Geneva: United 2011. Nations, Disponível em: $<$ https://www.ohchr.org/Documents/Publications/GuidingPrinciplesBusinessHR_EN.pdf>. Acesso em: 14 out. 2017.

UNRAVELLING the numbers. The Global Slavery Index. Disponível em: $<$ https://www.globalslaveryindex.org/findings/>. Acesso em: 10 maio 2017.

VALENTIN, João Hilário. Teletrabalho e relações de trabalho. Genesis: revista de direito do trabalho, Curitiba, v. 14, n. 82, p. 524-530, out. 1999.

VARELA, João de Matos Antunes. Das obrigações em geral (10 ed., Vol. I). Coimbra: Almedina, 2000.

VASCONCELOS, Marcia; BOLZON, Andréa. Trabalho forçado, tráfico de pessoas e gênero: algumas reflexões. Cad. Pagu, n. 31, p. 65-87, jul./dez. 2008. Disponível em: $<$ http://www.scielo.br/pdf/cpa/n31/n31a04.pdf $>$.

VENOSA, Silvio de Salvo. Direito civil: responsabilidade civil. 3. ed. São Paulo: Atlas, 2003.

VIANA, Márcio Túlio. Direito do trabalho e flexibilização. Em: BARROS, Alice Monteiro de (Coord.). Curso de direito do trabalho: estudos em memória de Célio Goyatá. São Paulo: LTr, 1997.

. A proteção social do trabalhador no mundo globalizado: o Direito do Trabalho no limiar do século XXI. Revista da Faculdade de Direito da Universidade Federal de Minas Gerais, Belo Horizonte, n. 37, p. 153-186, 2000. Disponível em: $<$ https://www.direito.ufmg.br/revista/index.php/revista/article/viewFile/1145/1078>. Acesso em: 23 maio 2018.

. A terceirização em perguntas e respostas: tentando diminuir as confusões. Blog $d a$ Boitempo, 01 abr. 2015. Disponível em: <https://blogdaboitempo.com.br/2015/04/01/oque-e-a-terceirizacao/>. Acesso em: 02 jun. 2018.

VIEIRA, Jorge Antônio Ramos. Trabalho escravo: uma chaga aberta. In: FÓRUM SOCIAL MUNDIAL, 3. 25 jan. 2003, Porto Alegre-RS. Anais... Brasília: OIT, 2003. Disponível em: <http://www.ilo.org/wcmsp5/groups/public/---americas/---ro-lima/---ilobrasilia/documents/publication/wcms_227275.pdf $>$.

VIEIRA NETO, Miguel Felinto. Responsabilidade solidária da grife pelo trabalho em condições análogas as de escravo em sua cadeia produtiva. In: PIMENTA, José Roberto Freire; MELLO FILHO, Luiz Philippe Vieira de; LOPES, Othon De Azevedo (Orgs.). Direito constitucional do trabalho princípios e jurisdição constitucional do TST. São Paulo: LTr, 2015. p. 165-177. 
VILASBOAS, Jaqueline Pereira de Oliveira. A capital goiana do jeans: flexibilidade, subcontratação e gênero no setor de confecção do município de Jaraguá-GO. 2015. Tese (Doutorado) - Programa de Pós-Graduação em Sociologia, Universidade Estadual de Campinas, Campinas, 2015.

VILELA, Magno. Uma questão de igualdade: Antônio Vieira e a questão negra na Bahia do século XVII. Rio de Janeiro: Relume Dumará, 1997.

VILELA, Rodolfo Andrade de Gouveia et al. Pressão por produção e produção de riscos: a 'maratona' perigosa do corte manual da cana-de-açúcar. Revista Brasileira de Saúde Ocupacional, v. 40, n. 131, p. 30-48, jan./jun. 2015. Disponível em: $<$ http://www.redalyc.org/html/1005/100541506005/>.

VILHENA, Paulo Emílio Ribeiro de. Relação de emprego: estrutura legal e supostos. São Paulo: LTr, 1999.

WALK FREE FOUNDATION. Disponível em: <https://www.walkfreefoundation.org>. Acesso em: 10 maio 2017.

WIEDEMANN, Thomas Ernst Josef. Greek and roman slavery. London; New York: Routledge, 1981.

WILliAMS, Eric. Capitalismo \& escravidão. 1. ed. Trad. D. Bottmann. São Paulo: Companhia da Letras, 2012.

WILSON, Larry C. The doctrine of wilful blindness. University of New Brunswick Law Journal - U.N.B.L.J., n. 28, p. 175-194, 1979. Disponível em: $<$ https:/heinonline.org/HOL/LandingPage?handle=hein.journals/unblj28\&div $=12 \& \mathrm{id}=\& \mathrm{p}$ age $=>$. Acesso em: 02 nov. 2018.

WITLEY, Richard. Business systems and global commodity chains: competing or complemetary forms of economic organizations? (S. P. UK, Ed.) Competition \& Change, v. 1, n. 4, p. 411-425, Dec. 1996.

ZARA é responsabilizada por trabalho escravo e pode entrar na "lista suja". Portal IG, Brasil Econômico, 14 nov. 2017. Disponível em: <https://economia.ig.com.br/2017-1114/zara-trabalho-escravo.html>. Acesso em: 15 maio 2018.

ZHANG, Liping; SCHIMANSKI, Silvana. Cadeias globais de valor e os países em desenvolvimento. Boletim de Economia e Politica Internacional (BEPI), n. 18, p. 73-92, set./dez. 2014.

Disponível

em:

$<$ http://www20.iadb.org/intal/catalogo/PE/2015/15323.pdf > . Acesso em: 26 maio 2018. 